\title{
Eggshell Powder as an Adsorbent for Removal of Fluoride from Aqueous Solution: Equilibrium, Kinetic and Thermodynamic Studies
}

\author{
R. BHAUMIK, N. K. MONDAL*, B. DAS , P. ROY, K. C. PAL, C. DAS, \\ A. BANERJEE, and J. K. DATTA \\ Department of Environmental Science, The University of Burdwan, WB, India. \\ nabakumar_mondal@indiatimes.com
}

Received 31 August 2011; Accepted 08 November 2011

\begin{abstract}
A new medium, eggshell powder has been developed for fluoride removal from aqueous solution. Fluoride adsorption was studied in a batch system where adsorption was found to be $\mathrm{pH}$ dependent with maximum removal efficiency at 6.0. The experimental data was more satisfactorily fitted with Langmuir isotherm model. The kinetics and the factor controlling adsorption process fully accepted by pseudo-second-order model were also discussed. $\mathrm{E}_{\mathrm{a}}$ was found to be $45.98 \mathrm{kJmol}^{-1}$ by using Arrhenius equation, indicating chemisorption nature of fluoride onto eggshell powder. Thermodynamic study showed spontaneous nature and feasibility of the adsorption process with negative enthalpy $\left(\Delta \mathrm{H}^{0}\right)$ value also supported the exothermic nature. Batch experiments were performed to study the applicability of the adsorbent by using fluoride contaminated water collected from affected areas. These results indicate that eggshell powder can be used as an effective, low-cost adsorbent to remove fluoride from aqueous solution as well as groundwater.
\end{abstract}

Keywords: Eggshell powder, Fluoride removal, Equilibrium, Kinetics, Thermodynamics.

\section{Introduction}

Fluorine, the most electronegative element is distributed ubiquitously as fluorides in nature ${ }^{1}$. Water is the major medium of fluoride intake by humans ${ }^{2}$. So the problems associated with the excess fluoride in drinking water are highly endemic and widespread in country like India $^{3}$. Many availablewater treatment technologies such as electro-dialysis ${ }^{4}$, Donnan dialysis $^{5}$ and reverse osmosis ${ }^{6}$ which are usually too expensive have been reported by previous researchers. The excessive fluoride intake leads to the loss of calcium from the tooth matrix, aggravating cavity formation throughout life ${ }^{7}$. Severe chronic and cumulative over exposure can cause the incurable cripping of skeletal fluorosis ${ }^{8}$. After recommendations of $\mathrm{WHO}$, a number of countries legislated to set $1.5 \mathrm{mg} / \mathrm{L}$ as the maximum contaminant level (MCL) for fluoride in drinking waters ${ }^{2}$. The traditional method of removing high 
fluoride contents from water is limiting followed by precipitation of fluorite ${ }^{9}$. Adsorption is an efficient and economically viable technology for the removal of fluoride. Recently, many naturally occurring materials such as activated carbon from plant materials ${ }^{10}$, bone-char powder $^{11}$, calcium alginate beads ${ }^{12}$, activated bauxite ${ }^{13}$, fly ash ${ }^{14}$, rice husk ${ }^{15}$, gibbsite ${ }^{16}$, kaolinite $^{16}$, brick powder ${ }^{17}$, used tea ash powder ${ }^{13}$, clay materials ${ }^{16}$, limestone ${ }^{18}$ and some commercially available adsorbent such as calcium hydroxide $\left[\mathrm{Ca}(\mathrm{OH})_{2}\right]$, calcium chloride $\left[\mathrm{CaCl}_{2}\right]$, and calcium sulphate $\left[\mathrm{CaSO}_{4}\right]^{19}$ have been used for removal of fluoride. Calcium containing materials were used by some researchers to remove fluoride from water ${ }^{19,20}$. Eggshell is mainly composed of calcium carbonate (94.03\%) and it also contains calcite and calcareous soil ${ }^{21}$. Eggshell has a cellulosic structure and contains amino acids; thus, it is expected to be a good biosorbent ${ }^{22}$ and it was reported that large amounts of eggshells are produced in some countries, as waste products and disposed in landfills annually ${ }^{23}$.

In present study eggshell powder has been used as a new low-cost adsorbent for the removal of $\mathrm{F}^{-}$from aqueous solution and groundwater sample. FTIR and SEM studies were carried out for the adsorbent characterization. The effects of various parameters such as $\mathrm{pH}$, adsorbent dose, contact time, initial concentration of fluoride and temperature were studied and discussed in detail in the following sections. The Langmuir, Freundlich, D-R and Tempkin isotherm models were used to describe the adsorption equilibrium data. The kinetics of the adsorption process was examined by fitting the experimental data with three kinetic models, i.e. pseudo-first-order and pseudo-second-order and intraparticle diffusion. The thermodynamic parameters, such as $\Delta \mathrm{G}^{0}, \Delta \mathrm{H}^{0}$ and $\Delta \mathrm{S}^{0}$ were also calculated from the adsorption measurements in the present study, which are very useful in elucidating the nature of adsorption.

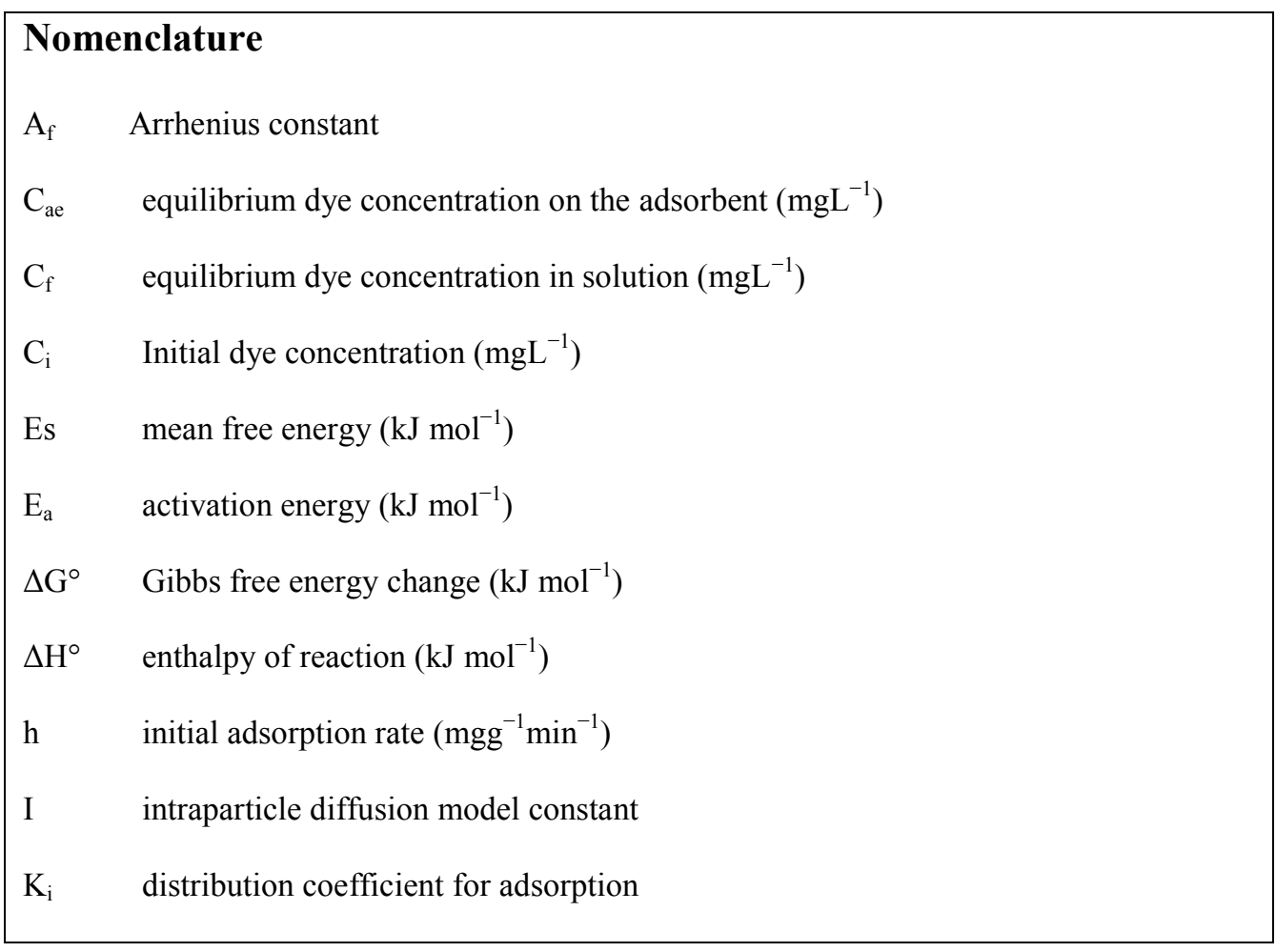




\begin{tabular}{|c|c|}
\hline $\mathrm{K}_{\mathrm{f}}$ & Freundlich constant $\left(\mathrm{mgg}^{-1}\right)\left(\mathrm{Lg}^{-1}\right)^{1 / \mathrm{n}}$ \\
\hline $\mathrm{b}$ & Langmuir constant $\left(\mathrm{Lmg}^{-1}\right)$ \\
\hline $\mathrm{R}_{\mathrm{L}}$ & Dimensionless equilibrium parameter \\
\hline $\mathrm{K}_{\mathrm{T}}$ & $\begin{array}{l}\text { Tempkin constant related to equilibrium binding constant } \\
\left(\mathrm{Lmg}^{-1}\right)\end{array}$ \\
\hline $\mathrm{B}_{1}$ & Tempkin constantrelated to the heat of adsorption \\
\hline $\mathrm{k}$ & rate constant \\
\hline $\mathrm{K}_{\mathrm{i}}$ & intraparticle diffusion rate constant $\left(\mathrm{mg} \mathrm{g}^{-1} \min ^{-0.5}\right)$ \\
\hline $\mathrm{k}_{1}$ & pseudo-first-order rate constant $\left(\mathrm{min}^{-1}\right)$ \\
\hline $\mathrm{k}_{2}$ & pseudo-second-order rate constant $\left(\mathrm{g} \mathrm{mg}^{-1} \mathrm{~min}^{-1}\right)$ \\
\hline W & weight of adsorbent (g) \\
\hline $\mathrm{n}$ & Freundlich adsorption isotherm constant \\
\hline $\mathrm{q}_{\mathrm{e}}$ & equilibrium dye concentration on adsorbent $\left(\mathrm{mgg}^{-1}\right)$ \\
\hline $\mathrm{q}_{\mathrm{m}}$ & maximum adsorption capacity $\left(\mathrm{mgg}^{-1}\right)$ \\
\hline $\mathrm{q}_{\mathrm{t}}$ & amount of dye adsorbed at time $\mathrm{t}\left(\mathrm{mgg}^{-1}\right)$ \\
\hline $\mathrm{R}$ & universal gas constant $\left(8.314 \mathrm{Jmol}^{-1} \mathrm{~K}^{-1}\right)$ \\
\hline $\mathrm{R}^{2}$ & correlation coefficient \\
\hline$\Delta \mathrm{S}^{\circ}$ & entropy of reaction $\left(\mathrm{Jmol}^{-1} \mathrm{~K}^{-1}\right)$ \\
\hline $\mathrm{T}$ & temperature $(\mathrm{K})$ \\
\hline $\mathrm{X}$ & volume of the solution (L) \\
\hline \multicolumn{2}{|c|}{ Greek alphabets } \\
\hline K & $\mathrm{D}-\mathrm{R}$ isotherm constant $\left(\mathrm{mmol}^{2} \mathrm{~J}^{-2}\right)$ \\
\hline$\varepsilon$ & polanyi potential $\left(\mathrm{Jmmol}^{-1}\right)=\mathrm{RT} \ln \left(1+1 / \mathrm{C}_{\mathrm{e}}\right)$ \\
\hline
\end{tabular}




\section{Materials and methods}

\section{Adsorbent collection and preparation}

Eggshells were collected from local market of Burdwan Municipality, Government of West Bengal, India and washed with double distilled water followed by drying in a hot air oven at $110^{\circ} \mathrm{C}$ for overnight $(12 \mathrm{hrs})$. The dried eggshells were grinded and sieved well in fraction of $100,150,250,300,350 \mu \mathrm{m}$ mesh size particles that were preserved in different sterilized containers for subsequent use as adsorbent.

\section{Instruments and apparatus}

The morphology of eggshell powder was learnt using SEM analyzer (HITACHI, S-530, Scanning Electron Microscope and ELKO Engineering). IR Spectrum of the eggshell powder was recorded on a PERKIN-ELMER, FTIR, Model RX1 Spectrometer. The $\mathrm{pH}$ of the solutions at the beginning and the end of the experiments were measured the average values by using Systronic 6.3 digital $\mathrm{pH}$ meter.Temperature controlled TARSONS, Spinot digital model MC02, CAT No. 6040, S. No. 173 magnetic stirrer was used during the adsorption experiments. Systronic Vis double beam Spectro- 1203 was used for colorimetric analysis. Analysis of fluoride was carried out by following SPANDS methods ${ }^{24}$.

\section{Preparation of adsorbate solution}

Stock solution of fluoride was prepared by dissolving $0.22 \mathrm{~g}$ sodium fluoride (MERCK, Germany) in $1 \mathrm{~L}$ double distilled water. The required concentration of fluoride solution was prepared by serial dilution of $100 \mathrm{mg} / \mathrm{L}$ fluoride stock solution.

\section{Zero point charge}

The point of zero charge of the adsorbent was determined by the solid addition method ${ }^{25}$. A $50 \mathrm{ml}$ of $0.1 \mathrm{M} \mathrm{KNO}_{3}$ solution transferred into a series of $100 \mathrm{ml}$ conical flask. The initial $\mathrm{pH}$ $\left(\mathrm{pH}_{0}\right)$ values of the solution was adjusted from 1.0 to 10.0 by adding either $0.05 \mathrm{~N} \mathrm{HNO}_{3}$ or $0.1 \mathrm{~N} \mathrm{KOH}$. Then $1.5 \mathrm{~g}$ of eggshell powder was added to each flask which was securely capped immediately. The flasks were then placed into a constant temperature water bath shaker and shaken for $24 \mathrm{~h}$. The $\mathrm{pH}$ values of the supernatant liquid were noted after $24 \mathrm{~h}$. The $\mathrm{pH}$ of the solution affects the surface charge of the adsorbents as well as the degree of the ionization and speciation of different pollutants. Change in the $\mathrm{pH}$ affects the adsorptive process through dissociation of functional groups as the active sites on the surface of the adsorbent. This subsequently leads to a shift in the reaction kinetics and the equilibrium characteristics of the adsorption process. Adsorption of the various anionic and cationic species on such adsorbents can be explained on the basis of the competitive adsorption of $\mathrm{H}^{+}$ and $\mathrm{OH}^{-}$ions with the adsorbate. It is a common observation that the surface adsorbs anions favorably at lower $\mathrm{pH}$ due to presence of $\mathrm{H}^{+}$ions, whereas the surface is active for the adsorption of cations at higher $\mathrm{pH}$ due to deposition of $\mathrm{OH}^{-}$ions ${ }^{25}$.

\section{Adsorption experiment and analysis}

Adsorption experiments were carried out for the determination of $\mathrm{pH}$, adsorbent dose variation, equilibrium time and kinetics, selection of an isotherm, effect of temperature and evaluation of thermodynamic parameters. The influence of $\mathrm{pH}(2.0-10.0)$, adsorbent dose $(0.2-2.4 \mathrm{~g} / 100 \mathrm{ml})$ and particle size $(200-350 \mu \mathrm{m})$,contact time $(20,40,60,80,120$ and 180 min), initial fluoride concentration $(1.5,3.0,5.0,7.0,10.0$ and $20.0 \mathrm{mg} / \mathrm{L})$ and temperature $(303,313,323$ and $333 \mathrm{~K})$ were evaluated during the present study in a $250 \mathrm{ml}$ Erlenmeyer flasks and $100 \mathrm{ml}$ of fluoride solution of known concentration was added. The contents 
(adsorbent/100ml solution) were kept for constant shaking (at $250 \mathrm{rpm}$ ) for $1 \mathrm{hr}$ in a temperature controlled magnetic stirrer at $303 \pm 1 \mathrm{~K}$ and then the solids were separated through filtration. The solutions were collected for analysis and fluoride concentration in the solution was determined by using spectrophotometer. Each experiment was conducted three times and average values are reported. Control experiments, performed without addition of adsorbent, confirmed that the sorption of fluoride on the walls of Erlenmeyer flasks was negligible. The amount of fluoride adsorbed per unit adsorbent (mg fluoride per g adsorbent) was calculated according to a mass balance on the fluoride concentration using Eq. (1):

$$
\mathrm{q}_{\mathrm{e}}=\left(\mathrm{C}_{\mathrm{i}}-\mathrm{C}_{\mathrm{f}}\right) \mathrm{X} / \mathrm{W}
$$

The percent removal (\%) of dyes was calculated using the following equation:

$$
\text { Removal }(\%)=\left(\mathrm{C}_{\mathrm{i}}-\mathrm{C}_{\mathrm{f}}\right) \times 100 / \mathrm{C}_{\mathrm{i}}(2)
$$

\section{Theory}

\section{Adsorption isotherm}

The adsorption characteristics of eggshell powder were determined using Freundlich ${ }^{26}$, Langmuir $^{27}$, Dubinin-Radishkevich ${ }^{28}$ and Tempkin ${ }^{29}$ isotherm models.

Freundlich:

$$
\mathrm{q}_{\mathrm{e}}=\mathrm{K}_{\mathrm{f}}\left(\mathrm{C}_{\mathrm{f}}\right)^{1 / \mathrm{n}}
$$

The Freundlich parameters were obtained by fitting the experimental data to the linerised equation derived from Eq.(3):

$$
\log \mathrm{q}_{\mathrm{e}}=\log \mathrm{K}_{\mathrm{f}}+1 / \mathrm{n} \log \mathrm{C}_{\mathrm{f}}(4)
$$

Langmuir:

$$
\mathrm{q}_{\mathrm{e}}=\left(\mathrm{q}_{\mathrm{m}} \mathrm{bCe}\right) /\left(1+\mathrm{bC}_{\mathrm{e}}\right)
$$

The Langmuir parameters were obtained by fitting the experimental data to the linearized equation derived from Eq. (5):

$$
1 / \mathrm{q}_{\mathrm{e}}=\left(1 / \mathrm{bq}_{\mathrm{m}}\right) 1 / \mathrm{C}_{\mathrm{f}}+1 / \mathrm{q}_{\mathrm{m}}(6)
$$

In order to predict the adsorption efficiency of the adsorption efficiency of the adsorption process, the dimensionless equilibrium parameter RL was determined by using the following equation30:

$$
\mathrm{R}_{\mathrm{L}}=1 /\left(1+\mathrm{b} \mathrm{C}_{0}\right)
$$


The parameter $R L$ indicates the shape of isotherm. The process is irreversible if $R L$ $=0$, favourable if $R L<1$, linear if $R L=1$ and unfavorable if $R L>1$.

Dubinin-Radushkevich (D-R) formulation:

$$
\mathrm{q}_{\mathrm{e}}=\mathrm{q}_{\mathrm{m}} \exp \left(-K \varepsilon^{2}\right)
$$

The constant $\mathrm{K}$ gives an idea about the mean free energy Es $\left(\mathrm{kJmol}^{-1}\right)$ of adsorption per mole of the adsorbate when it is transferred to the surface of the solid from infinity in the solution and can be from the equation 31 :

$$
\mathrm{E}_{\mathrm{s}}=1 / \sqrt{ } 2 K(9)
$$

The typical range of bonding energy for ion-exchange mechanisms is 8 and $16 \mathrm{~kJ}$ mol-1, indicating that chemisorption may play a significant role in the sorption process 32 , while for values of Es $<8 \mathrm{kJmol}-1$, the adsorption process is of a physical in nature 32 .

Tempkin:

$$
\mathrm{q}_{\mathrm{e}}=\mathrm{RT} \ln \left(\mathrm{K}_{\mathrm{T}} \mathrm{C}_{\mathrm{f}}\right) / \mathrm{b} \quad(10)
$$

Equation (10) can be linearized as in eq. (11):

$$
\mathrm{q}_{\mathrm{e}}=\mathrm{B}_{1} \ln \mathrm{K}_{\mathrm{T}}+\mathrm{B}_{1} \ln \mathrm{C}_{\mathrm{f}}(11)
$$

Where $\mathrm{B}_{1}=\mathrm{RT} / \mathrm{b}$

\section{Adsorption kinetics}

The pseudo-first-order, pseudo-second-order and intraparticle diffusion kinetic models were used to investigate the adsorption kinetics of fluoride and to quantify the extent of uptake in the adsorption process. A simple pseudo first-order kinetic model ${ }^{33}$, pseudo second-order model $^{34}$, intra-particle diffusion model ${ }^{35}$ are represented by the as given below:

Pseudo first-order:

$$
\log \left(\mathrm{q}_{\mathrm{e}}-\mathrm{q}_{\mathrm{t}}\right)=\log \left(\mathrm{q}_{\mathrm{e}}\right)-\left(\mathrm{K}_{1} / 2.303\right) \mathrm{t}(12)
$$

Pseudo second-order:

$$
\mathrm{t} / \mathrm{q}_{\mathrm{t}}=1 / \mathrm{K}_{2} \mathrm{q}_{\mathrm{e}}^{2}+\mathrm{t} / \mathrm{q}_{\mathrm{e}}
$$

The initial adsorption rate $\mathrm{h}\left(\mathrm{mg} \mathrm{g}^{-1} \mathrm{~min}^{-1}\right)$ is defined $\mathrm{as}^{34}$ :

$$
\mathrm{h}=\mathrm{k}_{2} \mathrm{q}_{\mathrm{e}}^{2}(14)
$$

The intra-particle diffusion:

$$
\mathrm{q}_{\mathrm{t}}=\mathrm{K}_{\mathrm{i}} \mathrm{t}^{0.5}+\mathrm{I}
$$

According to this model, if the plot of qe versus t 0.5 gives a straight line, then the adsorption process is controlled by intraparticle diffusion, while if the data exhibit multilinear plots, then two or more steps influence the adsorption process 36. 
Activation energy and thermodynamic parameters

The activation energy was calculated by using Arrhenius relation ${ }^{37}$ :

$$
\mathrm{k}=\mathrm{A}_{\mathrm{f}} \mathrm{e}^{-\mathrm{Ea} / \mathrm{RT}}(16)
$$

Converting Eq. (16) to linear form:

$$
\ln \mathrm{k}=\ln \mathrm{A}_{\mathrm{f}}-\mathrm{E}_{\mathrm{a}} / \mathrm{RT}
$$

In order to study the feasibility of the process, the thermodynamic parameters ware obtained from flowing equations:

$$
\begin{array}{r}
\mathrm{K}_{\mathrm{a}}=\mathrm{C}_{\mathrm{ae}} / \mathrm{C}_{\mathrm{f}}(18) \\
\mathrm{G}^{0}=-\mathrm{RT} \ln \mathrm{K}_{\mathrm{a}}(19) \\
\log \mathrm{K}_{\mathrm{a}}=\mathrm{S} / 2.303 \mathrm{R}-(\mathrm{H} / 2.303 \mathrm{TR})
\end{array}
$$

\section{Results and Discussion}

\section{Adsorbent characterization}

To understand the adsorption mechanism, it is necessary to determine the point of zero charge $\left(\mathrm{pH}_{\mathrm{PZC}}\right)$ of the adsorbent. Adsorption of anion is favored at $\mathrm{pH}<\mathrm{pH}_{\mathrm{PZC}}$ (Figure 1). The physico-chemical properties of the adsorbent are summarized in Table 1.

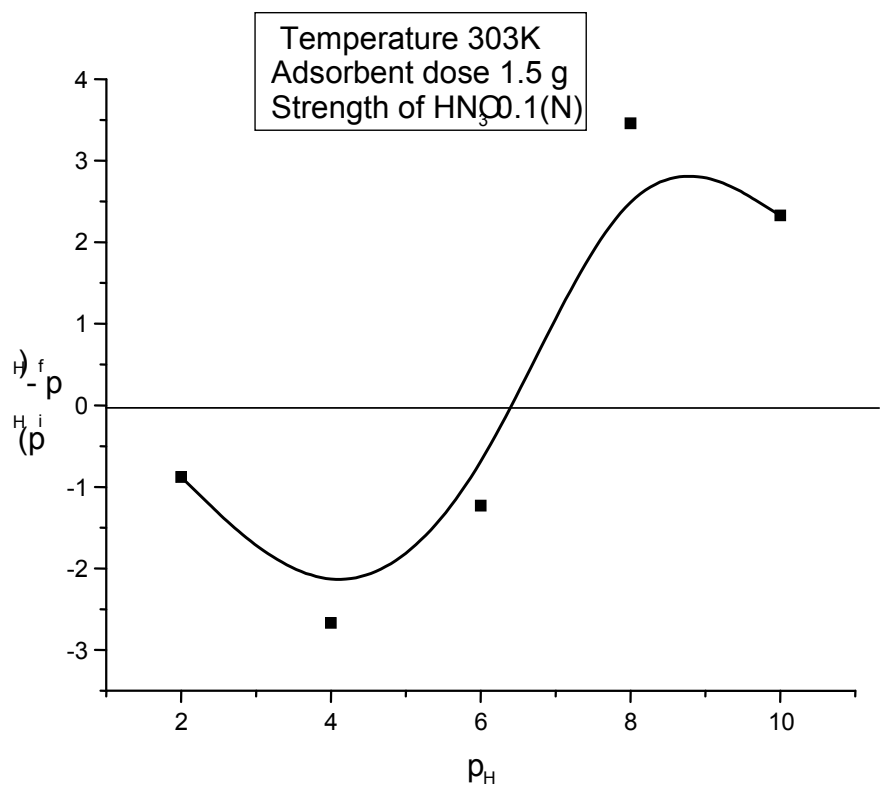

Figure 1. Zero Point charge of eggshell powder. 
The IR spectral analysis is important to identify the characteristic functional groups on the surface of the adsorbent, which are responsible for adsorption of fluoride ions 38,39 . The IR spectrum of eggshell powder was recorded to obtain the information regarding the stretching and bending vibrations of the functional groups which are involved in the adsorption of the adsorbate molecules. The IR spectra of eggshell powder before and after fluoride adsorption are shown in Figure $2 \mathrm{a}$ and Figure $2 \mathrm{~b}$. The IR spectral analysis of eggshell powder shows distinct peak at 712.86, 875.56, 2516.00, $3431.25 \mathrm{~cm}^{-1}$ (Figure 2a). The peak observed at 3431.25 and $2516.00 \mathrm{~cm}^{-1}$ may be assigned to the presence of alcohol hydroxyl group $(-\mathrm{OH})$ and acidic hydrogen group $(-\mathrm{OH})$ stretching respectively. This result suggests that fluoride interacts with metal oxides and $-\mathrm{OH}$ functional group present in eggshell powder. SEM analysis is another useful tool for the analysis of the surface morphology of an adsorbent. The porous and irregular surface structure of the adsorbent can be clearly observed in SEM images shown in Figure 3a. Further, the pores on the surface of the adsorbent are highly heterogeneous as shown in Figure $3 \mathrm{~b}$. The heterogeneous pores and cavities provided a lager exposed surface area for the adsorption of fluoride. The sizes of pores are indicative of the expected adsorption of fluoride molecules onto the surface of the adsorbent.

SEM images of eggshell powder before and after F- adsorption are shown in Figure $3 \mathrm{a}$ and Figure $3 \mathrm{~b}$. It clearly reveals the porous surface textures which endorse the adsorbent with increased surface area and high adsorption capacity. The SEM study also indicates that the treatment of fluoride solution influenced the orientation of the particles of the egg shells. The SEM image of untreated sample of eggshell exhibits non-adhesive appearance and formation of agglomerates, while treated sample shows regular, adhesive appearance causing further adsorption of fluoride3.

Table 1. Physico-chemical characteristics of eggshell powder.

\begin{tabular}{cc}
\hline Parameters & Values \\
\hline $\mathrm{pH}$ & 6.59 \\
\hline Electrical conductance $(\mathrm{mS})$ & 0.1 \\
\hline Specific gravity & 0.846 \\
\hline Moisture content $(\%)$ & 1.174 \\
\hline Bulk density $\mathrm{g} / \mathrm{cm}^{3}$ & 0.8024 \\
\hline Particle density $\mathrm{g} / \mathrm{cm}^{3}$ & 1.075 \\
\hline Porosity $(\%)$ & 25.4 \\
\hline BET Surface area $\left(\mathrm{m}^{2} / \mathrm{g}\right)$ & 21.2 \\
\hline pH & 6.3 \\
\hline Particle size $(\mu \mathrm{m})$ & $150-350$ \\
\hline
\end{tabular}




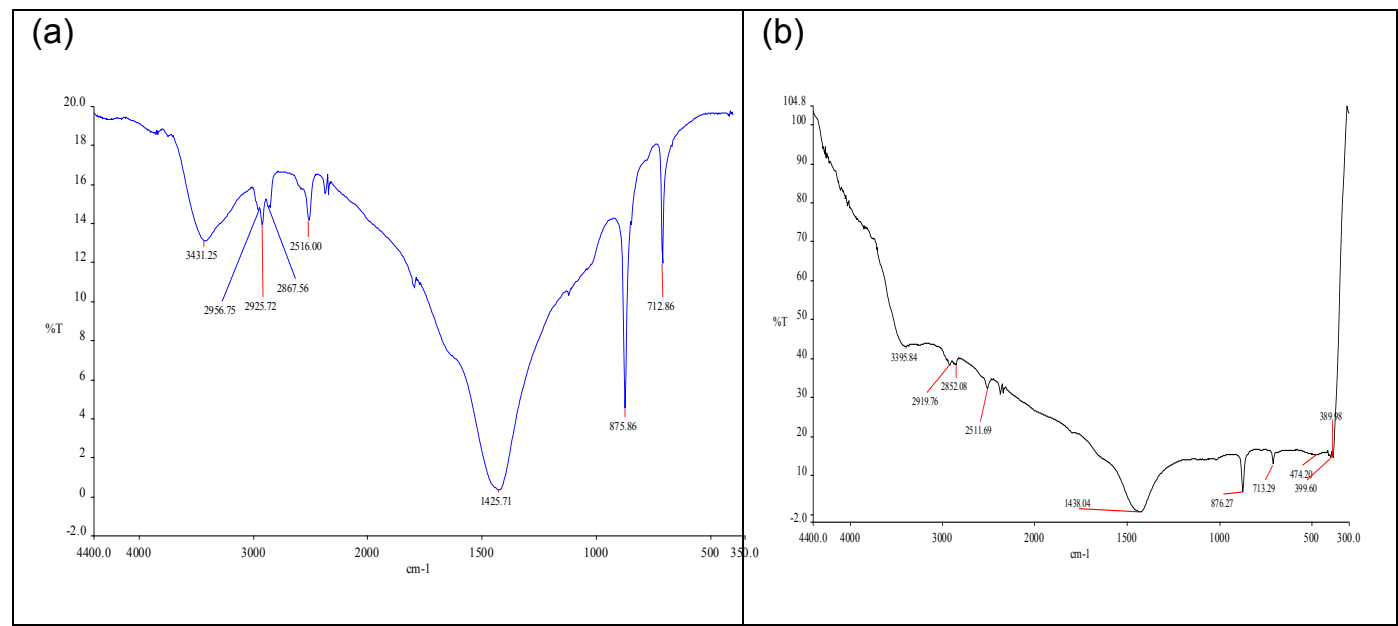

Figure 2. IR Spectrum of eggshell powder (a) before fluoride loaded and (b) after fluoride loaded.

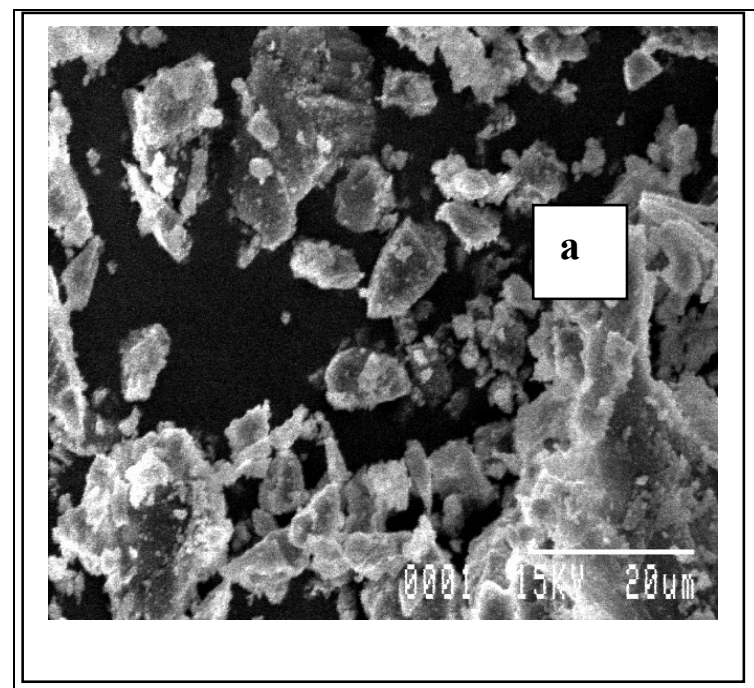

Figure 3(a). Scanning electron microscopy of egg shell before passing fluoride solution.

$\mathbf{a} \rightarrow$ Agglomerates.

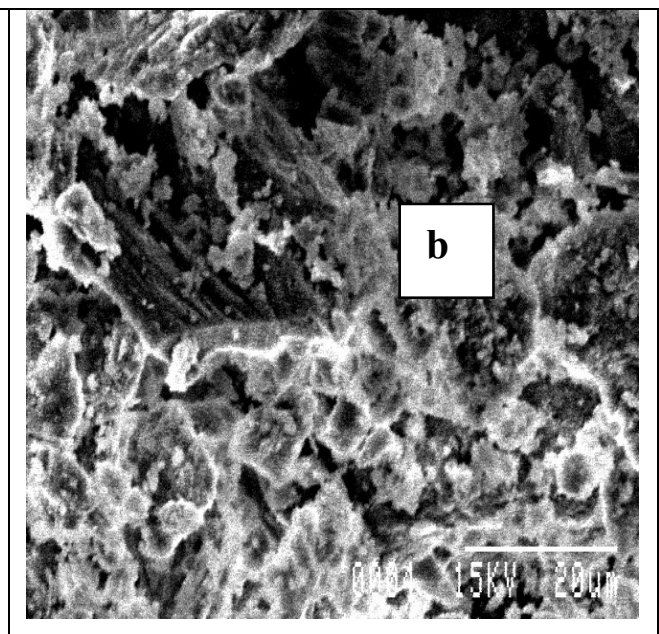

Figure 3(b). Scanning electron microscopy of egg shell after passing fluoride solution.

$\mathbf{b} \rightarrow$ Adhesive appearance.

\section{Effect of operating parameters}

\section{Effect of $\mathrm{pH}$}

The effect of $\mathrm{pH}$ on fluoride removal from aqueous solution by eggshell powder was studied at various $\mathrm{pH}$ values (ranging from 2-10). According to Turner et al., (2005)40 pH of solution affects the surface charge of the adsorbent material. In addition it is directly related with competition ability of $[\mathrm{H}+]$ with adsorbate ions to active sites on the adsorbent surface. 
The removal of fluoride by eggshell powder was noted to increase with increase in $\mathrm{pH}$ of the fluoride solution appreciably up to $\mathrm{pH} 6.0$ (Figure 4). The mechanism of fluoride removal can be better understood by examining the calcite surface composition ${ }^{41}$. Stipps $^{42}$ showed that $\mathrm{Ca}+2$ and $\mathrm{CO} 3$ - are only the PDIs (Potential determining ions) in a pure calcite solution and provided a modified electrical double layer model. Stipp's model proposes that along any cleavage point on the calcite surface, the calcium and carbonate ions have unsatisfied partial charges $(>\mathrm{Ca} \delta+$ and $>\mathrm{CO} 3 \delta$-, where $>$ represents the edge of the bulk calcite surface). This charge imbalance is decreased by the hydrolysis of water, resulting in the formation of $>\mathrm{Ca}-\mathrm{OH} \delta$ - and $>\mathrm{CO} 3-\mathrm{H} \delta+$ species. The formation of these species is thermodynamically favourable as the added hydrolysis layer lowers the potential with respect to the bulk calcite surface. These species can also react with any other ions in solution. For example, lower $\mathrm{pH}$ (increasing $\mathrm{H}+$ and $\mathrm{Ca} 2+$ ) causes an increase in positive sorption via the reactions ${ }^{41}$ :

$$
\begin{gathered}
\mathrm{Ca}-\mathrm{OH}^{\delta-}+\mathrm{H}^{+} \leftrightarrow>\mathrm{Ca}-\mathrm{OH}_{2}{ }^{\delta+} \leftrightarrow>\mathrm{Ca}^{\delta+}+\mathrm{H}_{2} \mathrm{O} \\
\mathrm{CO}_{3} \mathrm{H}^{\delta+}+\mathrm{Ca}^{+2} \leftrightarrow \mathrm{CO}_{3} \mathrm{Ca}^{\delta+}+\mathrm{H}^{+}
\end{gathered}
$$

At neutral to higher $\mathrm{pH}, \mathrm{OH}-$ and $\mathrm{CO} 32$ - dominate, producing $>\mathrm{CaCO} 3$ - and $>\mathrm{CO} 3+$ sorption $\operatorname{sites}^{43}$. Therefore, as well as providing more $\mathrm{Ca}^{2+}$ in solution from the dissolution of calcite, decreasing $\mathrm{pH}$ effectively increases the number of positive surface sites leading to an increase in the amount of fluoride removed from the system. On the other hand, under highly acidic conditions, the decrease may be attributed to the formation of weakly ionised hydrofluoric acid ${ }^{44}$ or the combined effects of chemical and electrostatic interaction between the calcite surface and the fluoride ions.

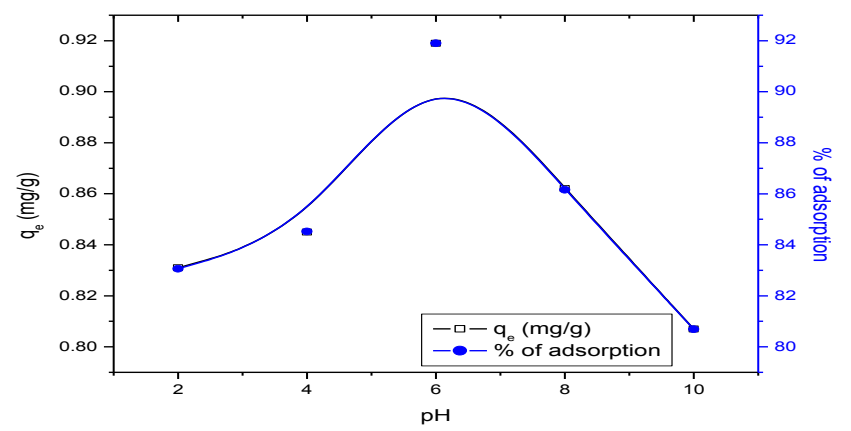

Figure 4. Effect of $\mathrm{pH}$ on the adsorption of fluoride by eggshell powder (experimental conditions: Initial fluoride concentration: $5.0 \mathrm{mg} / \mathrm{L}$, adsorbent dose: $0.5 \mathrm{~g} / 100 \mathrm{ml}$, agitation speed: $250 \mathrm{rpm}$, Contact time: 60 minutes, Temperature: $303 \mathrm{~K}$ ).

\section{Effect of adsorbent dose ( $g$ ) and particle size ( $\mu \mathrm{m}$ )}

Adsorbent dose is also an important parameter owing to its effect on efficiency (\%) and on the amount of fluoride adsorbed per unit weight of biomass $\left(\mathrm{q}_{\mathrm{e}}\right)$. Adsorption process is mainly depends upon the particle size of the adsorbent, small particle size larger surface area, increases the adsorption capacity. Hence, in this study the sorption capacity of an adsorbent dose and its particle size for a given initial concentration, contact time, agitation speed, temperature and $\mathrm{pH}$ at 6.0 were conducted. It was observed that percentage of fluoride removal increased with increasing of adsorbent dose (Figure 5). Such a trend is mostly attributed to an increase in the sorptive surface area and the availability of more 
active adsorption sites ${ }^{45}$. Figure 5 also shows the decrease of $\mathrm{q}_{\mathrm{e}}$ with increase of adsorbent dose might be due to the formation of aggregates between the eggshell powder particles at high adsorbent doses, reducing the effective active site area ${ }^{46}$. Similar observation has been reported for sorption of fluoride onto Ca-pretreated biomass ${ }^{46}$. Here another mechanism is also involved i.e. precipitation, according to Fan et al., ${ }^{47}$ fluorite is a better substrate for the removal of fluoride than calcite, with $\mathrm{F}^{-}$adsorbing onto exposed $\mathrm{Ca}$ sites parallel to the cleavage plane. It is possible, therefore, that fluorite precipitation increases the number of adsorption sites according to the following reactions:

$$
\begin{aligned}
\mathrm{CaCO}_{3}+\mathrm{H}^{+} \rightarrow \mathrm{Ca}^{+2}+\mathrm{HCO}_{3}^{-} \\
\mathrm{K}_{\mathrm{CaCO} 3}=\left[\mathrm{Ca}^{+2}\right]\left[\mathrm{HCO}_{3}^{-}\right] /\left[\mathrm{H}^{+}\right] \ldots \ldots \ldots . .
\end{aligned}
$$

Similarly, the fluoride equilibrium is:

$$
\begin{array}{r}
\mathrm{CaF}_{2} \rightarrow \mathrm{Ca}^{+2}+2 \mathrm{~F}^{-} \\
\mathrm{K}_{\mathrm{CaF} 2}=\left[\mathrm{Ca}^{+2}\right]\left[\mathrm{F}^{-}\right]^{2} \ldots \ldots \ldots \ldots \ldots \ldots
\end{array}
$$

This indicates that at constant $\mathrm{pH}$, activity of fluoride ion is directly proportional with the concentration of bicarbonate ion. Again, following principle of ionic activity product ${ }^{48}, \mathrm{CaF}_{2}$ precipitates when the concentration of $\mathrm{Ca}^{+2}$ and $\mathrm{F}^{-}$in water exceeds the solubility product of $\mathrm{F}^{-}$.

Performing the same experiment was carried out varying different particle size from $100 \mu \mathrm{m}-350 \mu \mathrm{m}$ (Figure 6a) with an initial fluoride concentration $(5 \mathrm{mg} / \mathrm{L})$, there is a very little difference $(<1.0 \%)$ in the amount of fluoride removed, suggesting that the removal mechanism is not limited by surface area at this concentration. Figure $6 \mathrm{~b}$ shows that for higher initial concentration $(20 \mathrm{mg} / \mathrm{L})$ there is a stronger dependence on particle size and surface area than compared to the lower initial concentration of fluoride. This result indicates, at equilibrium, fluoride removal increases with increasing solid-to-solid ratio, which suggest surface adsorption may be occurring and defluoridation mechanism by calcium carbonate cannot be described either by adsorption or precipitation alone ${ }^{40}$.

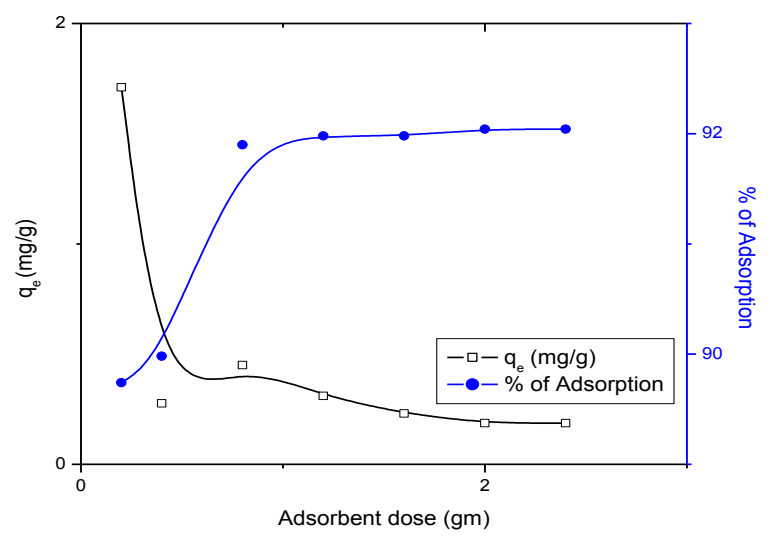

Figure 5. Effect of Adsorbent dose on the adsorption of fluoride by eggshell powder (experimental conditions: Initial fluoride concentration: $5.0 \mathrm{mg} / \mathrm{L}, \mathrm{pH}: 6.0$, agitation speed: 250 rpm, Contact time: 60 minutes, Temperature: $303 \mathrm{~K}$ ). 


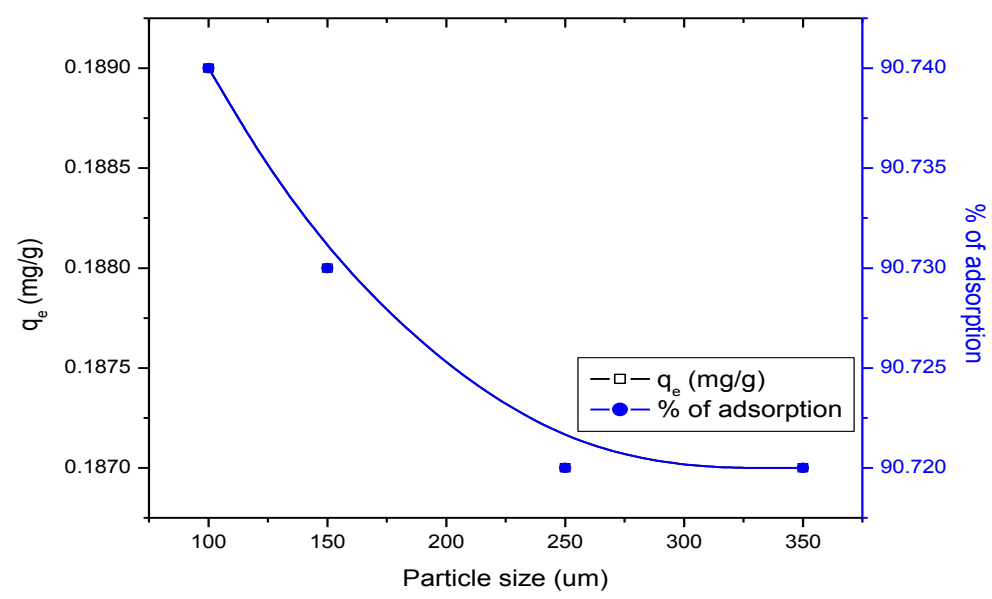

Figure 6a. Effect of particle size on the adsorption of fluoride by eggshell powder (experimental conditions: Initial fluoride concentration: $5.0 \mathrm{mg} / \mathrm{L}, \mathrm{pH}: 6.0$, adsorbent dose: $2.4 \mathrm{~g} / 100 \mathrm{ml}$, agitation speed: $250 \mathrm{rpm}$, Contact time: 60 minutes, Temperature: $303 \mathrm{~K}$ ).

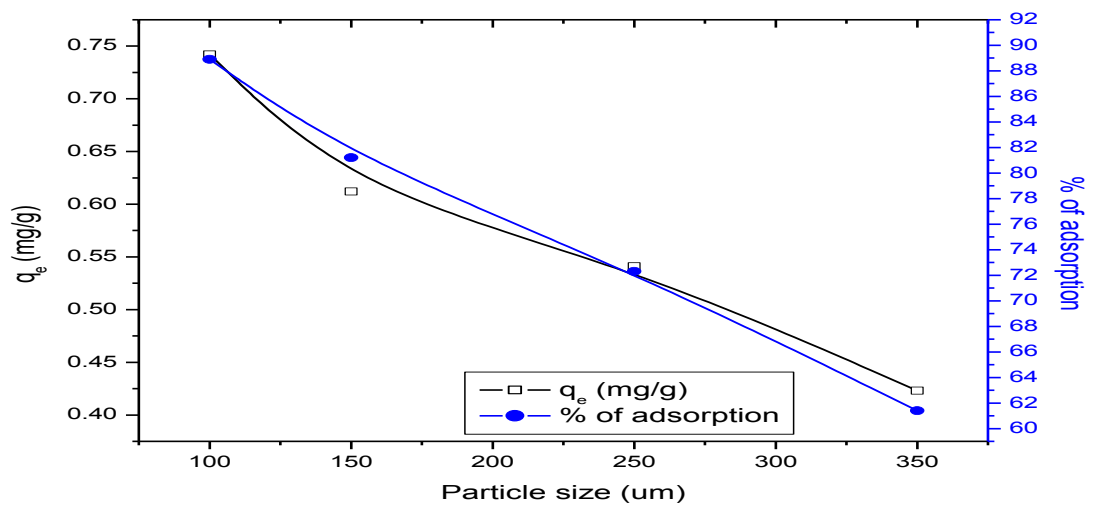

Figure 6b. Effect of particle size on the adsorption of fluoride by eggshell powder (experimental conditions: Initial fluoride concentration: $20.0 \mathrm{mg} / \mathrm{L}, \mathrm{pH}$ : 6.0, adsorbent dose: $2.4 \mathrm{~g} / 100 \mathrm{ml}$, agitation speed: $250 \mathrm{rpm}$, Contact time: 60 minutes, Temperature: $303 \mathrm{~K}$ ).

\section{Effect of agitation speed}

Studies on the effect of agitation speed were conducted by varying speeds from 150 to 350 $\mathrm{rpm}$, at optimum $\mathrm{pH}$ of 6.0 with adsorbent dose of $2.4 \mathrm{~g} / 100 \mathrm{ml}$ and contact time of 60 minutes at $313 \mathrm{~K}$. The influence of agitation speed on the extent of adsorption is shown in Figure 7. At a given time, fluoride removal increases with the increase in the speed of agitation. The reason for the increase in efficiency is that at higher speeds better contact between the adsorbent and adsorbate is possible ${ }^{49}$. Similar findings for fluoride removal by using activated charcoal have been reported by other investigator ${ }^{49}$. 


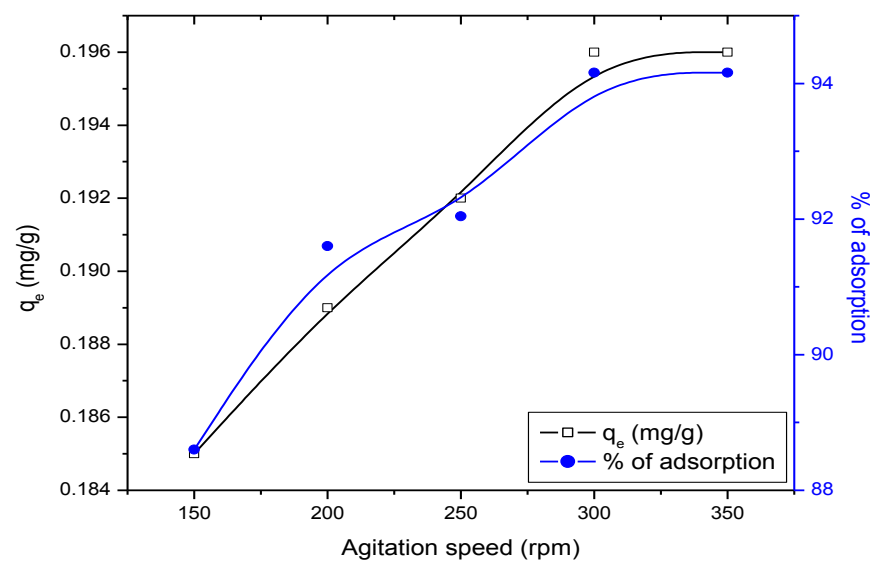

Figure 7. Effect of agitation speed on the adsorption of fluoride by eggshell powder (experimental conditions: Initial fluoride concentration: $5.0 \mathrm{mg} / \mathrm{L}, \mathrm{pH}: 6.0$, adsorbent dose: $2.4 \mathrm{~g} / 100 \mathrm{ml}$ and particle size $150 \mu \mathrm{m}$, agitation speed: $250 \mathrm{rpm}$, Contact time: 60 minutes, Temperature: $303 \mathrm{~K}$ ).

\section{Effect of Contact time}

It is essential to investigate the effect of contact time required to reach equilibrium for designing batch adsorption experiments. The fluoride removal capacity $\mathrm{q}_{\mathrm{e}}(\mathrm{mg} / \mathrm{g})$ on the eggshell powder $(2.4 / 100 \mathrm{ml})$ was determined by varying contact time $(20-180$ minutes $)$ for a given initial concentration and best $\mathrm{pH}(6.0)$ at $350 \mathrm{rpm}$. As illustrated in Figure 8, the adsorption of fluoride increased with rise in contact time upto $120 \mathrm{~min}$ and further increase in contact time did not enhance the fluoride adsorption process. The adsorption process attained equilibrium after $120 \mathrm{~min}$. The fast adsorption rate at the initial stage may be explained by an increased availability in the number of active binding sites on the adsorbent surface $^{50}$. The sorption rapidly occurs and normally controlled by the diffusion process from the bulk to the surface. Similar results were reported for adsorption of fluoride from aqueous solution onto tamarind seed, an unconventional biosorbent ${ }^{51}$.

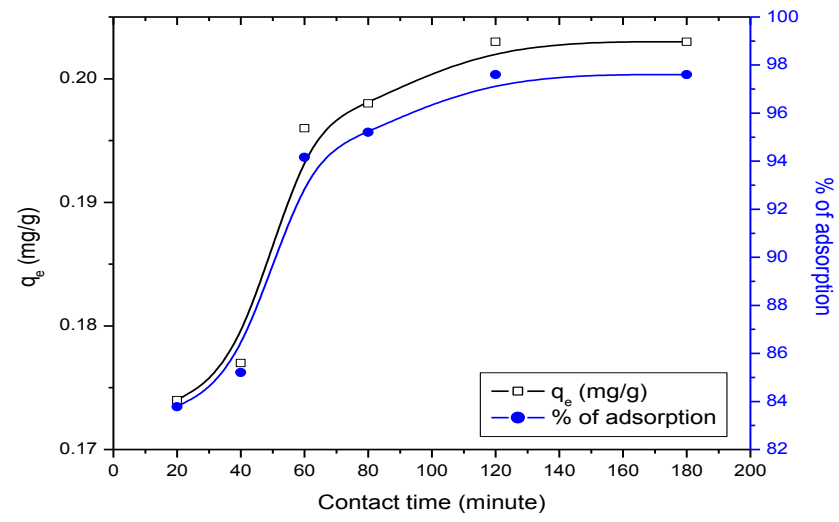

Figure 8. Effect of contact time on the adsorption of fluoride by eggshell powder (experimental conditions: Initial fluoride concentration: $5.0 \mathrm{mg} / \mathrm{L}, \mathrm{pH}$ : 6.0, adsorbent dose: $2.4 \mathrm{~g} / 100 \mathrm{ml}$ and particle size $150 \mu \mathrm{m}$, agitation speed: $350 \mathrm{rpm}$, Temperature: $303 \mathrm{~K}$ ). 


\section{Effect of Initial concentration}

The efficiency of fluoride adsorption for different initial $\mathrm{F}^{-}$concentrations ranging from 1.5 to $20.0 \mathrm{mg} / \mathrm{L}$ was investigated by carrying out adsorption experiments at the best experimental conditions present in Figure 9. The percentage removal of fluoride decreased with increase in initial fluoride concentration and reached in equilibrium condition at higher concentrations. This is probably due to the fact that for a fixed adsorbent dose, the total available adsorption sites are limited, which become saturated at a certain concentration ${ }^{50}$. Due to increasing concentration gradient, acts as increasing driving force to overcome all mass transfer resistances of the fluoride between the aqueous and solid phase, leading to an increasing equilibrium sorption until sorbent saturation is achieved. Similar trend has been reported for fluoride removal by geo-materials ${ }^{52}$ and activated charcoal ${ }^{50}$.

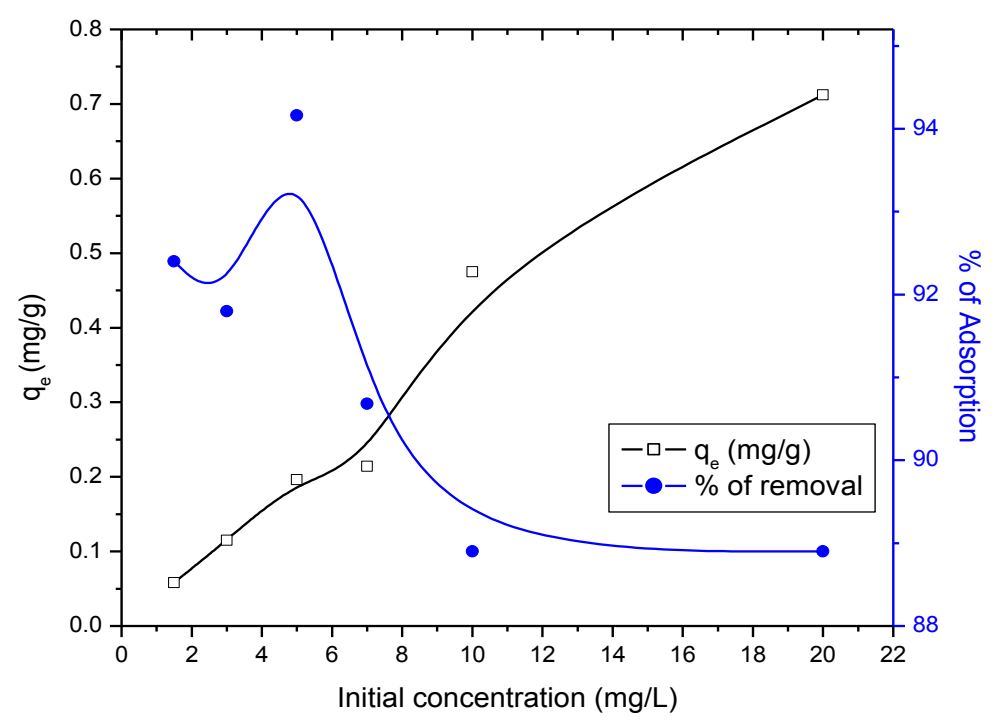

Figure 9. Effect of Initial concentration on the adsorption of fluoride by eggshell powder (experimental conditions: $\mathrm{pH}$ : 6.0, adsorbent dose: $2.4 \mathrm{~g} / 100 \mathrm{ml}$ and particle size $150 \mu \mathrm{m}$, agitation speed: $350 \mathrm{rpm}$, contact time: 100 minutes, Temperature: $303 \mathrm{~K}$ ).

\section{Effect of temperature}

It is well established that temperature is an additional factor greatly influence any adsorption process. The effect of solution temperature was investigated at 303, 313, 323 and $333 \mathrm{~K}$. The results summarized in Figure 10, indicating the adsorption rate or precipitation as $\mathrm{CaF}_{2}$ decreased with increase in temperature. This result indicates low temperature favours the removal of fluoride molecules by adsorption onto eggshell as well as the adsorption process is exothermic in nature. The decreasing of removal may be due to at high temperature the thickness of the boundary layer decreases due to increased tendency of the molecules to escape from the adsorbent surface to the solution phase, which results in a decrease in the adsorption capacity as temperature is increased ${ }^{53}$. Similar results were previously reported by Sujana and Anand ${ }^{3}$. 


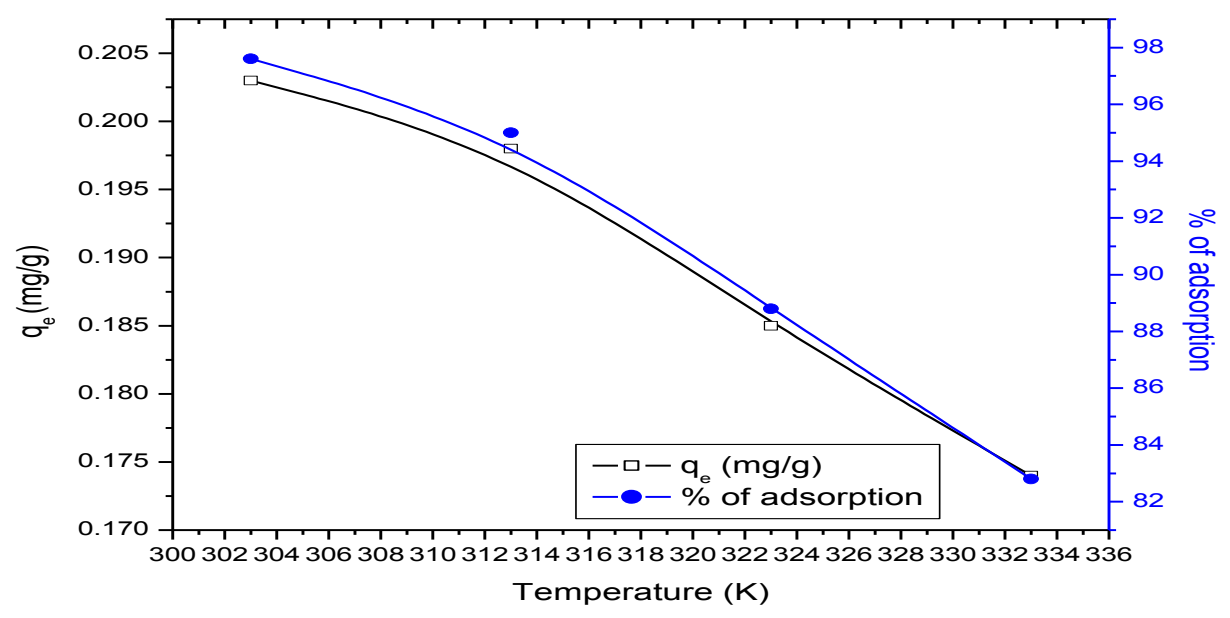

Figure 10. Effect of temperature on the adsorption of fluoride by eggshell powder (experimental conditions: Initial fluoride concentration: $5.0 \mathrm{mg} / \mathrm{L}, \mathrm{pH}$ : 6.0, adsorbent dose: $2.4 \mathrm{~g} / 100 \mathrm{ml}$ and particle size $150 \mu \mathrm{m}$, agitation speed: $350 \mathrm{rpm}$, Temperature: $303 \mathrm{~K}$ ).

\section{Adsorption isotherm}

In this investigation, the Freundlich, the Langmuir, the Dubinin-Radushkevich and the Tempkin were used to describe the equilibrium data acquired at different temperatures (in the range from 303-333K). The results are shown in Table 2 and the modeled isotherms are plotted in Figure 11. According to Table 2, the Langmuir isotherm model showed excellent fit to the experimental data with high correlation coefficients at all temperatures. The maximum fluoride sorption capacity of eggshell powder was found to be $1.09 \mathrm{mg} / \mathrm{g}$ at 303 $\mathrm{K}$. The constant $\mathrm{K}_{\mathrm{L}}$, represents the affinity between the adsorbent and adsorbate. The values of $\mathrm{K}_{\mathrm{L}}$ and $\mathrm{q}_{\mathrm{m}}$ decreased with increase in temperature (Table 2), the magnitude of the Langmuir constant $\mathrm{K}_{\mathrm{L}}$ has small values $(0.02-0.04 \mathrm{~L} / \mathrm{mg})$, which indicates a low heat of adsorption capacity ${ }^{54,55}$.

The empirical Freundlich model also showed a fairly good fit to the experimental equilibrium data at all temperatures studied $\left(\mathrm{R}^{2}>0.99\right)$. The values of $\mathrm{K}_{\mathrm{f}}$ from the Freundlich model are an indicator of the adsorption capacity of a given adsorbent ${ }^{32}$. From the Table 2 , the sorption capacity $\left(\mathrm{K}_{\mathrm{f}}\right)$ decreased with increase in temperature which implies the sorption process as exothermic in nature ${ }^{54}$ and lower value for $\mathrm{K}_{\mathrm{f}}$ indicates that the rate of adsorbate removal is low $^{56}$.The ' $n$ ' should have values lying in the range of 1-10 for classification as favorable adsorption ${ }^{57}$. A smaller value of $n($ Table 2) indicates a weaker bond between adsorbate and adsorbent ${ }^{58,59}$.

In order to distinguish between physical and chemical sorption on the heterogeneous surfaces the equilibrium data were tested with D-R isotherm model. The correlation coefficients in D-R model were found to be lower than the Freundlich and 
Langmuir isotherm models (Table 2). The constant $K$ gives an idea about the mean free energy $\left(\mathrm{E}_{\mathrm{s}}\left(\mathrm{kJmol}^{-1}\right)\right)$ of adsorption per mole of the adsorbate when it is transferred to the surface of the solid from infinity in the solution. In this study the magnitude of $E_{s}$ were higher than $8 \mathrm{kJmol}^{-1}$ at all studied temperatures which indicate the adsorption mechanism of fluoride onto eggshell powder was chemisorption.

As seen in Table 2, a decrease in the temperature produced a decrease in the adsorption capacity in Tempkin isotherm models. The fitness of the adsorption data to the Langmuir isotherm implies that the binding energy on the whole surface of the adsorbent was uniform and that sorbate-sorbate interaction was negligible. It also indicates that the adsorbed fluoride did not interact or complete with each other and they were adsorbed by forming a monolayer ${ }^{32}$. Table 3 summarizes the comparison of the maximum fluoride adsorption capacities of various sorbents including eggshell powder. The comparison shows that eggshell powder has similar adsorption capacity of fluoride as like as other reported adsorbents, reflecting a promising utility for eggshell (waste material as shown in restaurants and hotels) powder utilization in fluoride removal from contaminated water, because in this study removal of $\mathrm{F}^{-}$from groundwater has also been investigated described later.

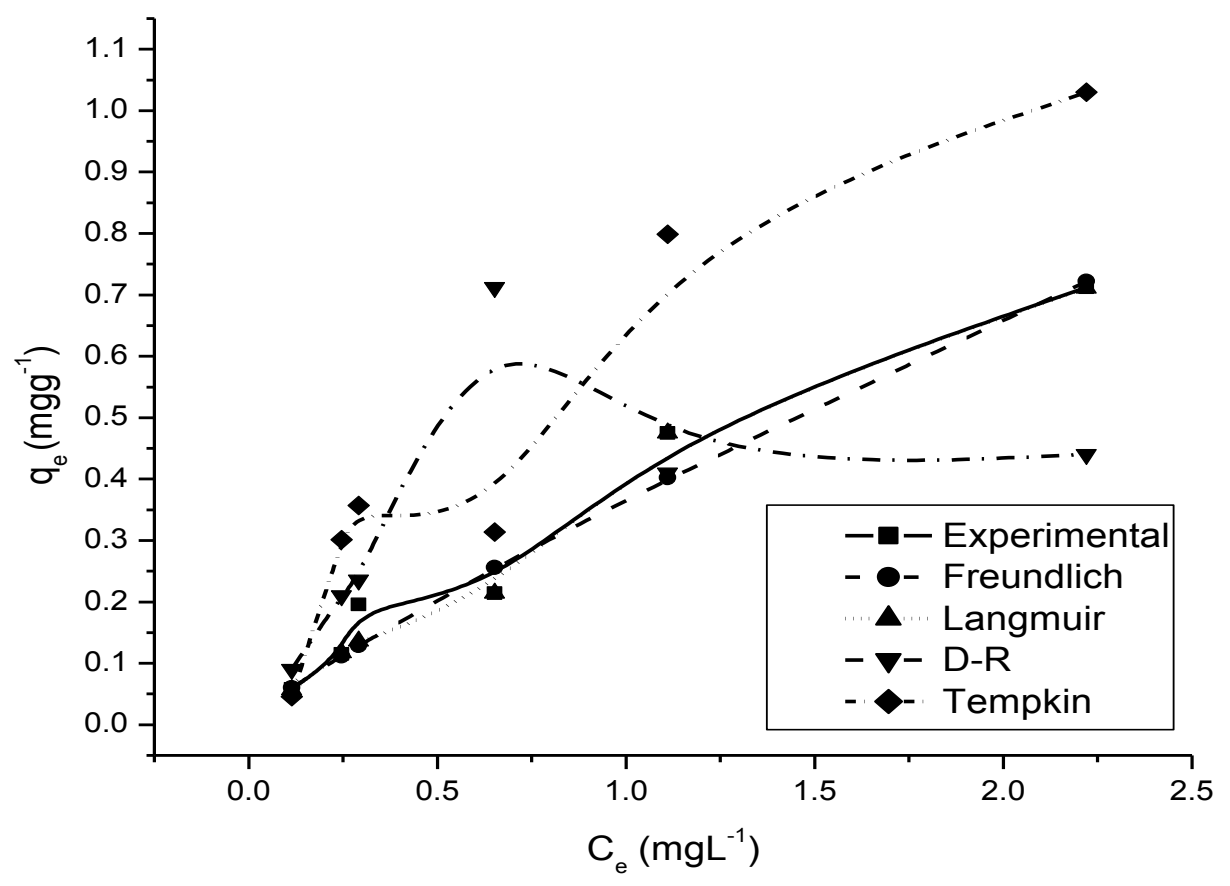

Figure 11. Comparison between the measured and modeled isotherm profiles for the adsorption of fluoride by using eggshell powder on different initial concentration $\left(\mathrm{mg}^{-1} \mathrm{~L}\right)$ : (experimental condition $\mathrm{pH}$ of the solution: 6.0, adsorbent dose: $2.4 \mathrm{~g} / 100 \mathrm{ml}$, particle size: $150 \mu \mathrm{m}$, agitation speed: $350 \mathrm{rpm}$, Contact time: 100 minutes, Temperature: $303 \mathrm{~K}$ ). 
Table 2. Adsorption isotherm constants for adsorption of fluoride onto eggshell powder at different temperatures.

\begin{tabular}{|c|c|c|c|c|c|c|c|c|c|c|c|c|c|}
\hline \multirow{2}{*}{ 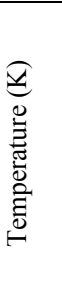 } & \multicolumn{3}{|c|}{ Langmuir isotherm } & \multicolumn{3}{|c|}{ Freundlich isotherm } & \multicolumn{4}{|c|}{$\mathrm{D}-\mathrm{R}$ isotherm parameters } & \multicolumn{3}{|c|}{ Tempkin } \\
\hline & $\mathrm{q}_{\mathrm{m}}$ & $\overbrace{\vec{J}}^{\stackrel{-10}{\Xi}}$ & $\mathrm{R}^{2}$ & 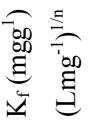 & $\mathrm{n}$ & $\mathrm{R}^{2}$ & 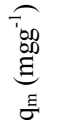 & K & $\mathrm{E}_{\mathrm{s}}$ & $\mathrm{R}^{2}$ & $\mathrm{~B}_{1}$ & $\mathrm{~K}_{\mathrm{T}}$ & $\mathrm{R}^{2}$ \\
\hline 303 & 1.09 & 0.488 & 0.998 & 0.368 & 1.18 & 0.997 & 0.464 & $\begin{array}{l}2.343 \\
\times 10^{-3}\end{array}$ & 14.59 & 0.953 & 0.331 & 10.09 & 0.939 \\
\hline 313 & 1.08 & 0.412 & 0.995 & 0.341 & 1.11 & 0.983 & 0.411 & $\begin{array}{l}2.412 \\
\times 10^{-3}\end{array}$ & 13.93 & 0.907 & 0.316 & 7.39 & 0.868 \\
\hline 323 & 1.06 & 0.289 & 0.979 & 0.334 & 1.09 & 0.969 & 0.378 & $\begin{array}{c}2.68 \times \\
10^{-3} 3\end{array}$ & 13.64 & 0.888 & 0.235 & 5.59 & 0.865 \\
\hline 333 & 1.02 & 0.193 & 0.954 & 0.311 & 1.06 & 0.951 & 0.292 & $\begin{array}{l}2.811 \\
\times 10^{-3}\end{array}$ & 13.25 & 0.872 & 0.211 & 3.57 & 0.861 \\
\hline
\end{tabular}

Table 3. Comparison of fluoride adsorption capacity of eggshell powder with other reported low-cost-adsorbents.

\begin{tabular}{ccc}
\hline Sorbent & $\mathrm{q}_{\max }(\mathrm{mg} / \mathrm{g})$ & Reference \\
\hline Activated carbon from Dolichos lab lab & 0.233 & 57 \\
\hline Activated carbon from Acacia Arabica & 2.06 & 58 \\
\hline Tamarind seed & 6.09 & 51 \\
\hline Crude fibre content from neem,pipal and Khair & 0.04 & 59 \\
\hline Gibbsite & 0.4 & 16 \\
\hline Kaolinite & 0.2 & 16 \\
\hline Dolomite & $0.21-0.29$ & 16 \\
\hline Smectite & 0.33 & 16 \\
\hline Kaolinite & 0.07 & 65 \\
\hline Brick powder & 0.55 & 17 \\
\hline Used Tea powder & 0.054 & 17 \\
\hline Ca-pretreated macrophyrte biomass & 0.110 & 46 \\
\hline Eggshell & 1.09 & Present study \\
\hline
\end{tabular}

\section{Adsorption kinetics}

As mentioned before, three kinetic models i.e. pseudo-first-order, pseudo-second-order and intraparticle diffusion model were applied to investigate the reaction pathways and potential rate limiting steps of the adsorption of fluoride onto eggshell powder.

The pseudo-first-order rate constant, $\mathrm{k}_{1}$ and the equilibrium adsorption capacity, $\mathrm{q}_{\mathrm{e}}$ at different temperatures were determined from the slope and intercept of the plots of log $\left(\mathrm{q}_{\mathrm{e}}-\mathrm{q}_{\mathrm{t}}\right)$ versus $\mathrm{t}$ and are listed in Table 4 along with the correlation coefficient $\left(\mathrm{R}^{2}\right)$. From the 
kinetic data in Table 4, a large difference between theoretical and experimental equilibrium adsorption capacity, $\mathrm{q}_{\mathrm{e}}$, is observed at all temperatures, indicating a poor fit of the pseudofirst-order equation to the experimental data.

The pseudo-second-order model constants were determined from the slope and intercept of the plot of $t / q_{t}$ versus $t$. The plot of $t / q_{t}$ against $t$ at different temperatures is shown in Figure 12. Contrary to the pseudo-first-order equation, the fitting of the kinetic data in the pseudo-second-order equation showed excellent linearity with high correlation coefficient $\left(\mathrm{R}^{2}>0.999\right)$ over the temperature range of 303-333 K. It is also observed from Table 4 that rate constant, $\mathrm{k}_{2}$ decreased as the temperature increased indicating exothermic nature of adsorption of fluoride onto eggshell powder. Furthermore, the calculated $\mathrm{q}_{\mathrm{e}}$ values were found to be quite close to the experimental $\mathrm{q}_{\mathrm{e}}$ values at all temperatures studied (303$333 \mathrm{~K})$. So, it was inferred that the adsorption of fluoride onto eggshell followed pseudosecond-order kinetics. This finding suggests that the rate-limiting step of the adsorption system may be chemisorption. The initial adsorption rate, $\mathrm{h}\left(\mathrm{mgg}^{-1} \mathrm{~min}^{-1}\right)$, decreased with increase in temperature (Table 4) suggesting that adsorption of fluoride onto eggshell was not favourable at higher temperatures.

The intraparticle diffusion was investigated using the empirical relationship based on the removal of Weber-Morris (Eq.(15)). The results (Table 4) corresponds to the external surface uptake and based on these results it might be concluded that intraparticle diffusion was involved in fluoride adsorption onto eggshell powder, but it was not the sole rate determining step and that some other mechanism also play an important role. Similar trend has already been reported for fluoride adsorption from contaminated ground water by using bauxite . $^{3}$

Table 4. Kinetics parameters for adsorption of fluoride onto eggshell powder at different temperatures.

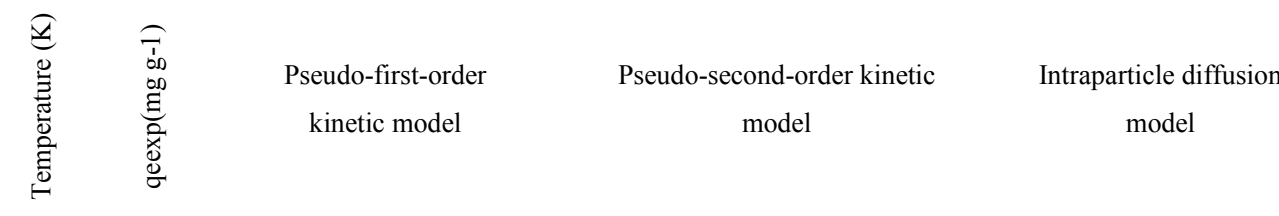

\begin{tabular}{|c|c|c|c|c|c|c|c|c|c|c|c|}
\hline & & 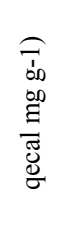 & 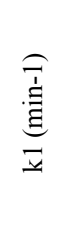 & $\mathrm{R} 2$ & 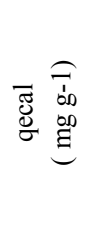 & k2 & 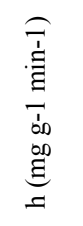 & $\mathrm{R} 2$ & 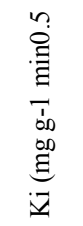 & $\begin{array}{l}\widehat{C} \\
\dot{b} \\
00 \\
\Xi \\
\Xi \\
\vdots\end{array}$ & $\mathrm{R} 2$ \\
\hline 303 & 0.203 & 0.014 & 0.052 & 0.723 & 0.212 & 4.685 & 0.211 & 0.999 & 0.004 & 0.169 & 0.903 \\
\hline 313 & 0.198 & 0.013 & 0.014 & 0.722 & 0.21 & 1.047 & 0.045 & 0.995 & 0.003 & 0.164 & 0.861 \\
\hline 323 & 0.185 & 0.012 & 0.014 & 0.722 & 0.19 & 0.844 & 0.03 & 0.994 & 0.002 & 0.163 & 0.863 \\
\hline 333 & 0.174 & 0.011 & 0.013 & 0.721 & 0.18 & 0.796 & 0.026 & 0.987 & 0.016 & 0.155 & 0.862 \\
\hline
\end{tabular}




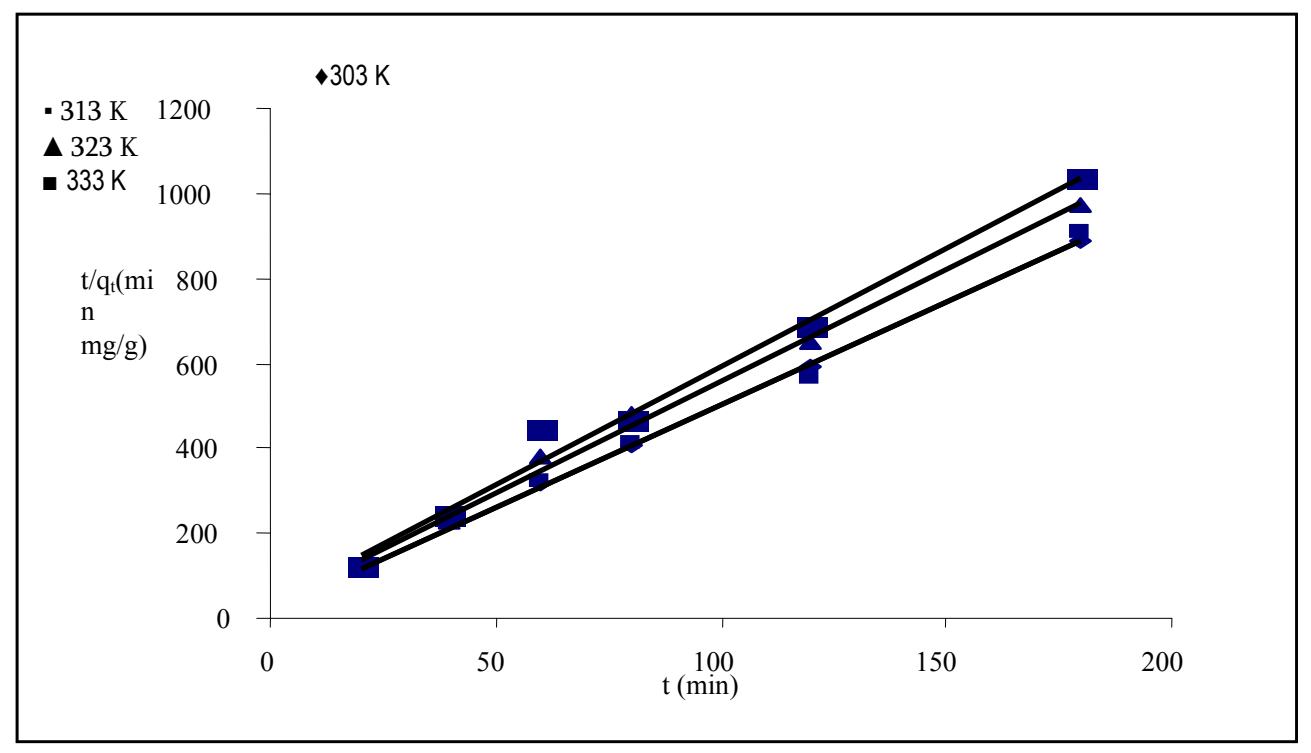

Figure 12. Pseudo-second-order kinetic plots for adsorption of fluoride onto eggshell powder at different temperatures (experimental conditions: Initial dye concentration: 5.0 $\mathrm{mg} / \mathrm{L}$, adsorbent dose: $2.4 \mathrm{~g} / 100 \mathrm{ml}$, Particle size: $150 \mu \mathrm{m}$ agitation speed: $350 \mathrm{rpm}, \mathrm{pH}: 6.0$, Temperature $303 \mathrm{~K})$.

\section{Activation energy and thermodynamic parameters}

From the pseudo-second-order rate constant $K_{2}$ (Table 4), the activation energy $E_{a}$ for adsorption of fluoride onto eggshell powder was determined using Arrhenius equation (Eq.(16)). By plotting $\ln \mathrm{K}_{2}$ verses $1 / \mathrm{T}$ (Figure not shown), $\mathrm{E}_{\mathrm{a}}$ was obtained from the slope of the linear plot. The value of $\mathrm{E}_{\mathrm{a}}$ for fluoride adsorption on eggshell powder was $45.98 \mathrm{~kJ}$ $\mathrm{mol}^{-1}$. The magnitude of activation energy may give an idea about the type of sorption. In the present study, the value of the activation energy confirms that the nature of fluoride adsorption onto eggshell is chemisorption ${ }^{50}$. The Gibbs free energy $\left({ }^{\Delta} G^{0}\right)$ for adsorption of fluoride onto eggshell at all temperatures was obtained from Eq.19 and presented in Table 5. The values of ${ }^{\Delta} \mathrm{H}^{0}$ and ${ }^{\Delta} \mathrm{S}^{0}$ were determined from the slope and intercept of the plot of ${ }^{\Delta} \mathrm{G}^{0}$ versus $T$ (Figure 13) and are also listed in Table 5. The negative value of $\Delta^{0}$ at all temperatures indicates the feasibility of the process and the spontaneous nature of the adsorbate onto adsorbent. Increase in value of ${ }^{\Delta} \mathrm{G}^{0}$ with increase in temperature suggests that higher temperature makes the adsorption unfavourable. The negative value of ${ }^{\Delta} \mathrm{H}^{0}$ implies that the adsorption phenomenon is exothermic and obtained entropy ${ }^{\Delta} \mathrm{S}^{0}\left(-0.162 \mathrm{Jmol}^{-1} \mathrm{~K}^{-1}\right)$ indicates that the process is enthalpy driven ${ }^{50}$. 


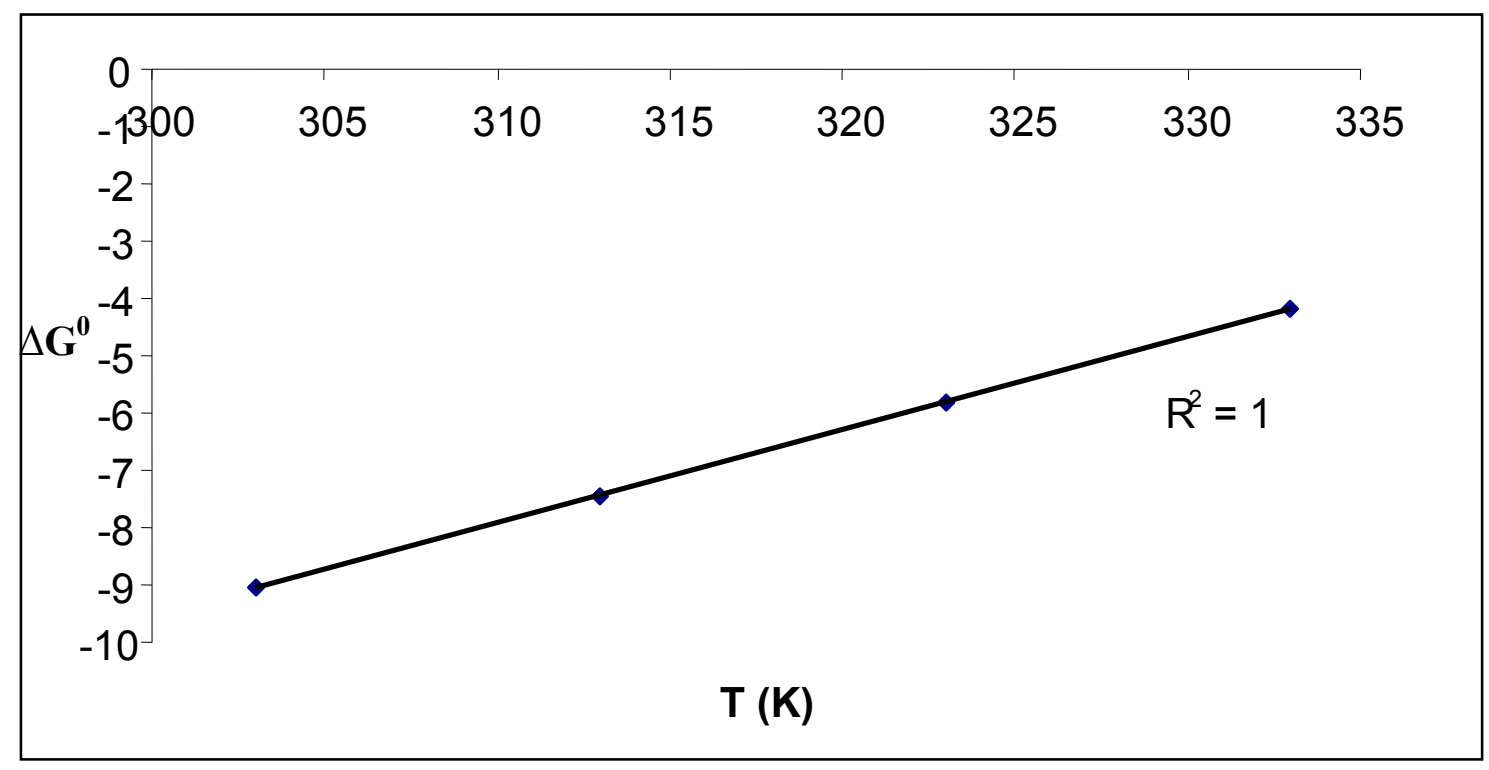

Figure 13. Plot of Gibb's free energy change versus temperature for adsorption of fluoride onto eggshell powder.

\section{Cost analysis and removal of $F$ from ground water}

With a view to making use of this finding in domestic applications eggshell powder is an effective and low-cost adsorbent for removal of fluoride from drinking water as well as groundwater. The overall cost of the adsorbent material is governed by several factors which include its availability (whether it is natural, industrial/agricultural/domestic wastes or byproducts or synthesized by-products), the processing required and reuse. Eggshell is available in abundance as a domestic waste product and collected from target site. The most popular commercial adsorbents of the present time for removal of fluoride are activating charcoal, activated alumina etc. Compared to these commercially available adsorbents, the total cost of eggshell powder is extremely low. In this study, use of eggshell powder can fulfill its effectiveness as an adsorbent for removal of $\mathrm{F}^{-}$through batch techniques from contaminated ground water samples collected form different locations (villages), Nasipur and Nowapara of Birbhum district in West Bengal, India. Analysis of these samples was carried out and given in Table 6 with high $\mathrm{F}^{-}$concentrations in ground water obtained from Nasipur and Nowapara in Birbhum district. The batch adsorption studies were carried out as such as normal conditions with concentration variation of eggshell powder dose $(2.4 \mathrm{~g})$ for 100 minutes of constant agitation at $350 \mathrm{rpm}$ in temperature controlled magnetic stirrer at $303 \mathrm{~K}$. The results show that the $\mathrm{F}^{-}$levels in the ground water samples collected from study area decreased to $<1 \mathrm{mg} / \mathrm{L}$ with $2.4 \mathrm{~g} / 100 \mathrm{ml}$ of eggshell powder. Thus the use of eggshell powder is a thoughtful and economic attempt for its valuable, necessitous and needy utilization for contaminated groundwater treatment process in affected areas. 
Table 5. Activation energy and thermodynamic parameters for adsorption of fluoride onto eggshell powder.

\begin{tabular}{|c|c|c|c|c|c|c|}
\hline \multirow{2}{*}{$\begin{array}{l}\mathrm{E}_{\mathrm{a}}(\mathrm{kJ} \\
\left.\mathrm{mol}^{-1}\right)\end{array}$} & \multicolumn{4}{|c|}{$\Delta \mathrm{G}^{0}\left(\mathrm{~kJ} \mathrm{~mol}^{-1}\right)$} & \multirow{2}{*}{$\begin{array}{c}\Delta \mathrm{H}^{0}(\mathrm{~kJ} \\
\left.\mathrm{mol}^{-1}\right)\end{array}$} & \multirow{2}{*}{$\begin{array}{c}\Delta \mathrm{S}^{0} \\
\left(\mathrm{Jmol}^{1}{ }^{1}\right)\end{array}$} \\
\hline & $303 \mathrm{~K}$ & $313 \mathrm{~K}$ & $323 \mathrm{~K}$ & $333 \mathrm{~K}$ & & \\
\hline 45.98 & -9.063 & -7.7443 & -5.823 & -4.203 & -58.149 & -0.162 \\
\hline
\end{tabular}

Table 6. Physico-chemical analysis of groundwater samples collected from study area (Nasipur and Nowpara).

\begin{tabular}{ccc}
\hline Parameters & Nasipur & Nowapara \\
\hline $\mathrm{pH}$ & 7.2 & 7.7 \\
\hline Conductivity $(\mathrm{mS} / \mathrm{cm})$ & 2.8 & 3.0 \\
\hline Fluoride $\left(\mathrm{mg} \mathrm{L}^{-1}\right)$ as $\left(\mathrm{F}^{-}\right)$ & $\mathbf{7 . 1}$ & $\mathbf{1 0 . 0}$ \\
\hline Total hardness $\left(\mathrm{mg} \mathrm{L}^{-1}\right)$ as $\mathrm{Ca}$ and $\mathrm{Mg}$ & 944 & 31.48 \\
\hline Chloride $\left(\mathrm{mg} \mathrm{L}^{-1}\right)$ as $\left(\mathrm{Cl}^{-}\right)$ & & 112.2 \\
\hline Sulphate $\left(\mathrm{mg} \mathrm{L}^{-1}\right)$ as $\left(\mathrm{SO}_{4}^{-2}\right)$ & 545.93 & 0.048 \\
\hline Phosphate $\left(\mathrm{mg} \mathrm{L}^{-1}\right)$ as $\left(\mathrm{PO}_{4}^{-2}\right)$ & 186 & 0.095 \\
\hline Ammonical nitrogen $\left(\mathrm{mg} \mathrm{L}^{-1}\right)$ & 16 & 24 \\
\hline COD $\left(\mathrm{mg} \mathrm{L}^{-1}\right)$ & 1.53 & 0.153 \\
\hline Iron (mg L & & \\
\hline
\end{tabular}

\section{Conclusions}

The role of eggshell powder as an adsorbent for removal of fluoride from aqueous solution using batch technique has been established. The maximum adsorption occurred at $\mathrm{pH}$ 2.0-6.0. Experimental equilibrium data provided best fit with the Langmuir isotherm model, indicating monolayer sorption on a homogenous surface (maximum monolayer sorption capacity was $1.09 \mathrm{mg} \mathrm{g}^{-1}$ at $303 \mathrm{~K}$ ). According to Dubinin-Radishkevich (D-R) isotherm model, adsorption of fluoride onto eggshell powder was Chemisorption. The adsorption kinetics followed pseudo-second-order kinetic model indicating towards chemisorption. Intra-particle diffusion was not the sole rate controlling factor. The activation energy of the adsorption process $\left(\mathrm{E}_{\mathrm{a}}\right)$ was found to be $45.98 \mathrm{kJmol}^{-1}$ by using Arrhenius equation, indicating chemisorption nature of fluoride onto eggshell powder also. Thermodynamic analysis suggests that removal of fluoride from aqueous solution by eggshell powder was a spontaneous and exothermic process. The eggshell powder has also been encouraging results with groundwater sample collected from villages (Nasipur and 
Nowapara) in Birbhum district, West Bengal, India. The present findings suggest that such eggshell is an expensive as a waste material available in many parts of the world, it also can provide a simple, effective and low cost method for removing $\mathrm{F}^{-}$form contaminated water.

\section{References}

1. Kugali N M and Yadawe M S, Pollution of drinking water due to fluoride and dentalfluorosis at Hunagundtaluk of Bagalkot district, Karnataka, Inter $J$ Appl BioPharmaTechno, 2010, 1(2), 322-328.

2. WHO, Guidelines for Drinking Water Quality, World Health Organization, Geneva, 2006.

3. Rao N C R, Fluoride And Environment- A Review in Martin J. Bunch, V. MadhaSuresh, T. V. Kumaran, eds., Proceedings of the Third International Conference on Environment andHealth, Chennai, India, 2003, 386-399.

4. Adhikary S K, Tipnis U K, Harkare W P and Govindan K P, Defluoridation during desalination of brackish water by electrodyalysis, Desalination, 1989, 71, 301-312.

5. Hichor M, Persin F, Sandeaux J and Gavach C, Fluoride removal from waters by Donan dialysis, SeperSciTechnol 2000, 18(1), 1-11.

1. 6.Ndiaye P I, Moulin P, Domingwez L, Millet Z C andCharbit F, Removal of fluoride from electronic industrial effluent by RO membrane separation, Desalination, 2005, 173, 25-32.

6. Sujana M G, and Anand S, Fluoride removal studies from contaminated ground water by using bauxite, Desalination, 2011, 267(2-3), 222-227.

7. UNICEF Statement on fluoride in water: (2004)HYPERLINK "http://www.fluoride.org.uk/"http://www.fluoride.org.uk/statements/000000_unicef.htm.

8. Emamjomeh M M, Sivakumar $\mathrm{M}$ and Schafer A I, An empirical model forv defluoridation by batch monopolar electrocoagulation/flotation (ECF) process, J Hazard Mater, 2006, 131, 118-125.

9. Kumar S, Gupta A and Yadav J P, Removal of fluoride by thermally activated carbonprepared from neem(Azadirachtaindica) and kikar (Acacia arabica) leaves, $J$ EnvironBio, 2008, 29(2), 227-232.

10. Bhargava D S and Killedar D J, Batch Studies of Water Defluoridation UsingFishbone Charcoal, J WatPollutContFeder, 1991, 63(6), 848-858.

11. Vijaya $\mathrm{Y}$ and Krishnaiah A, Column adsorption and desorption studies of fluoride onperchloric acid crossed-linked calcium alginate beads, E-Journal of chemistry, 2010,7(1), 265-270.

12. Munavalli G R, Patki V K, A comparative study of defluoridation techniques,J JPHE 2009, 10(2), 36-43.

13. Goswami D and Das K A, Removal of fluoride from drinking water using a modifiedfly ash adsorbent, J SciInd Res, 2006, 65, 77-79.

14. Deshmukh W S, Attar S J and Waghmare M D, Investigation on Sorption of Fluoridein Water Using Rice Husk as an Adsorbent, Nat Environ PollutTechnol, 2009, 8(2),217223.

15. Coetzee P P, Coetzee L L, Puka R and Mubenga S, Characterizations of selectedSouth African clays for defluoridation of natural waters, Water SA, 2003, 29(3), 331-338.

16. Wijesundara T, Low Cost Defluoridation of Water Using Broken Bricks, 30thWEDC International Conference Vientiane, Lao PDR, 2004.

17. Nath S K and Dutta R K, Fluoride removal from water using crushed limestone. Ind. J ChemTechnol, 2010, 17, 120-125. 
18. Vigneswaran S and Visvanathan C, Water Treatment Processes, Simple Options(CRC) press, new work 1995.

19. Turner B D, Binning P and Stipp S L S, Fluoride removal by calcite: Evidencefluorite precipitation and surface adsorption, Environ SciTechnol, 2005, 39 9561-9568.

20. Wenming D, Zhijun G, Jinzhou D, Liying Z and Suzi T, Sorption characteristics ofzinc (II) by calcareous soil-radiotracer study, ApplRadiat Isotopes, 2001, 54(3)371-375.

21. Abdel-jabbar N and Al-asheh S, Factorial Design for the Analysis of PackedbedSorption of Copper using Eggshell as a Biosorbent, J Environ ProtecSci, 2009, 3133 139.

22. Kalyani G, Rao B and Saradhi V, Equilibrium and kinetic studies on biosorption ofzinc onto Gallus domesticus shell powder, J EngApplSci, 2009, 4, 39-49.

23. Clesceri L S, Greenberg A E, Standard Methods for the Examination of Water andWastewater Eaton A D, 20th ed.; APHA, AWWA, WEF: Washington, DC, 1998; 482.

24. Mondal $\mathrm{M} \mathrm{K}$, Removal of $\mathrm{Pb}$ (II) from aqueous solution by adsorption usingactivated tea waste, Korean J ChemEng, 2010, 27(1), 144-151.

25. Freundlich H, Over the adsorption in solution, Z PhysChem, 1906, 57(A), 385.

26. Langmuir I, The constitution and fundamental properties of solids and liquids, JAm ChemSoc, 1916, 38, 2221.

27. Oguz E, Thermodynamic and kinetic investigations of PO43- adsorption on blastfurnace slag, J Colloid InterfSci, 2005, 281, 62.

28. Wasewar K L, Kumar S and Prasad B, Adsorption of Tin Using Granular ActivatedCarbon, J Environ ProtecSci, 2009, 3, 41-52.

29. Magdy $\mathrm{Y} \mathrm{H}$ and Daifullah A A M, Adsorption of a basic dye from aqueous solutionsonto sugar-industry-mud in two modes of operations, Waste Manag, 1988, 18(4),219-226.

30. Kalavathy $\mathrm{H}$, Karthik $\mathrm{B}$ and Miranda L R, Removal and recovery of $\mathrm{Ni}$ and $\mathrm{Zn}$ fromaqueous solution using activated carbon from Heveabrasiliensis: Batch and columnstudies, Colloid Surf B: Biointerf, 2010, 78, 291-302.

31. Chowdhury S and Saha P, Sea-shell powder as a new adsorbent to remove BasicGreen4 (Malachite green) from aqueous solutions: Equilibrium, kinetic andthermodynamic studies, ChemEng J, 2010, 164, 168-177.

32. Lagergren S, About the theory of so-called adsorption of soluble substances, derSogenanntenadsorptiongelosterstoffeKungligaSvenskaVetenskapsalka de MiensHandlingar, 1898, 2, 41-39.

33. Ho Y S, Porter J F and McKay G, Equilibrium isotherm studies for the sorption ofdivalent metal ions onto peat: copper, nickel and lead single component systems, Water Air Soil Pollut, 2002, 141, 1-33.

34. Weber $\mathrm{W}$ J and Morris J C, Kinetics of adsorption on carbon from solution, J SanitEngDiv Am Soc Civil Eng, 1963, 89, 31.

35. Gao J, Zhang Q, Su K, Chen R and Peng Y, Biosorption of acid yellow 17 fromaqueous solution by non-living aerobic granular sludge, J Hazard Mater, 2010,174(1-3), 215-225.

36. Lu H, M. Luan and Zhang J, A kinetic study on the Adsorption of Chromium (VI)onto a natural Material used as Landfill Liner. EJGE, 2009, 14, 1-10.

37. Ahalya N, Kanamadi R D and Ramachandra T V, Biosorption of chromium (VI) fromaqueous solutions by the husk of Bengal gram (Cicerarientum), Electron JBiotechnol, 2005, 8.

38. Shen S, Samaranayake, L P and Yip H K, In vitro growth, acidogenicity andcarcinogenicity of predominant human root caries flora, J Dent, 2004, 32, 667-678. 
39. Turner B D, Philip B and Stipp S L S, Fluoride Removal by Calcite: Evidencefor Fluorite precipitation and surface adsorption, Environ SciTechnol, 2005, 39(24),95619568.

40. Munagapati V S, Yarramuthi V, Nadavala S K, Alla S R and Abburi K, Biosorptionof $\mathrm{Cu}$ (II), $\mathrm{Cd}$ (II) and $\mathrm{Pb}$ (II) by Acacia leucocephala bark powder: kinetics, equilibrium and thermodynamics, ChemEng J, 2010, 157(2-3), 357-365.

41. Stipp S L S, Toward a conceptual model of the calcite surface: Hydration,hydrolysis, and surface potential, GeochimCosmochimActa, 1999, 63, 3121-3131.

42. Fenter P, Geissbuhler P, DiMas E, Srajer G, Sorenson L B and Sturchio N C, Surfacespeciation of calcite observed in situ by high-resolution x-ray reflectivity, GeochimCosmochimActa, 2006, 4(a), 1221-1228.

43. Sujana M G, Thakur R S and Rao S B, Removal of fluoride from aqueous solutionusing alum sludge, J Colloid InterfSci, 1998, 206, 94-101.

44. Chowdhury S, Misha R, Saha P and Kushwaha P, Adsorption thermodynamics,kinetics and isosteric heat of adsorption of malachite green onto chemically modifiedrice husk, Desalination, 2011, 265(1-3), 159-168.

45. Miretzky P, Munoz $\mathrm{C}$ and Carrillo-Chavez A, Fluoride removal from aqueoussolution by Ca-pretreated macrophyte biomass, Environ Chem, 2008, 5, 68-72.

46. Fan X, Parker D J and Smith M D, Adsorption kinetics of fluoride on low costMaterials, Water Res, 2003, 37, 4929-4937.

47. Nezil I E, Achor S, Djidel M. Attalah S, Presence and origin of fluoride in thecomplex Terminal water of Ouragla Basin (Northern Sahara of Algeria), American JApplSci, $2009,6(5)$ 876-881.

48. Tembhurkar A R and Dongre S, Studies on fluoride removal using adsorptionprocess, $\mathrm{J}$ Environ SciEng, 2006, 48(3),151-156.

49. Saha P, Chowdhury S, Gupta S, Kumar I, Insight into adsorption equilibrium,kinetics and thermodynamics of Malachite Green onto clayey soil of Indian Origin,ChemEng J, 2010, 165(3), 874-882.

50. Murugan M, and Subremanian E, Studies on defluoridation of water by tamarindseed, an unconventional biosorbent, J Water Health, 2006, 4, 453-461.

51. Sujana M G, Padhan H K, Anand S, Studies on sorption of some geomaterials forfluoride removal form aqueous solutions, J Hazard Mater, 2009, 161, 120-125.

52. Bhatti H N, Nasir A W and Hanif M A, Efficacy of Daucuscarota L. waste biomassfor the removal of chromium from aqueous solutions, Desalination, 2010, 253, 78-87.

53. Dogan M, Alkan M, Türkyılmaz A and Özdemir Y, Kinetics and mechanism ofremoval of methylene blue by adsorption onto perlite, J Hazard Mater, 2004,109(B), 141-148.

54. Pandey K K Prasad G and Singh V N, Removal of Cr(VI) from aqueous solution byadsorption on fly ash wollastonite, J ChemTechnolBiotechnol, 1984, 34(A), 367-374.

55. Ajmal M, Mohammad A, Yousuf R and Ahmad A, Adsorption behaviour ofcadmium, zinc, nickel and lead from aqueous solution by Magnifier indica seedshell, Ind J Environ Health, 1998, 40(1), 15-26.

56. Rao M V B, Rao M S , Prasanthi V, Ravi M, Characterization and defluoridationstudies of activated Dolichos lab lab carbon, Rasayan J Chem, 2009, 2(2), 525-530.

57. Kishorea $M$ and Hanumantharao $Y$, Validation of defluoridation method with "acaciaarabica"plant byproduct through 2nd factorial experimentation-statistical approach,Inter J Appl Bio PharmaTechnol, 2010, 1(3), 1230-1235.

58. Jamode A V, Sapkal V S, Jamode V S, Defluoridation of water using inexpensiveadsorbents, J Indian InstSci, 2004, 84, 163-171. 


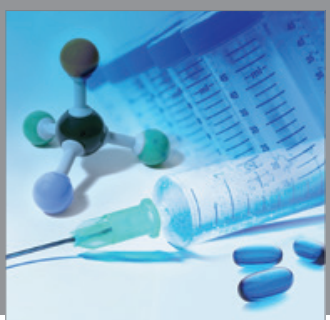

International Journal of

Medicinal Chemistry

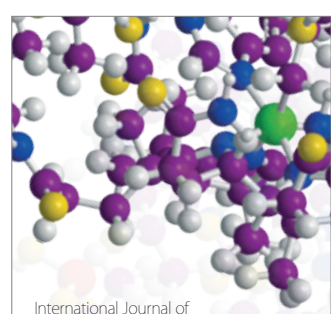

Carbohydrate Chemistry

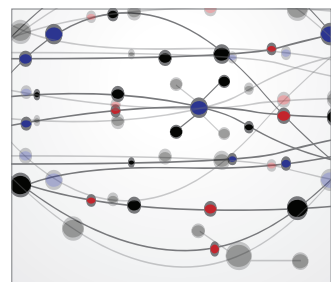

The Scientific World Journal
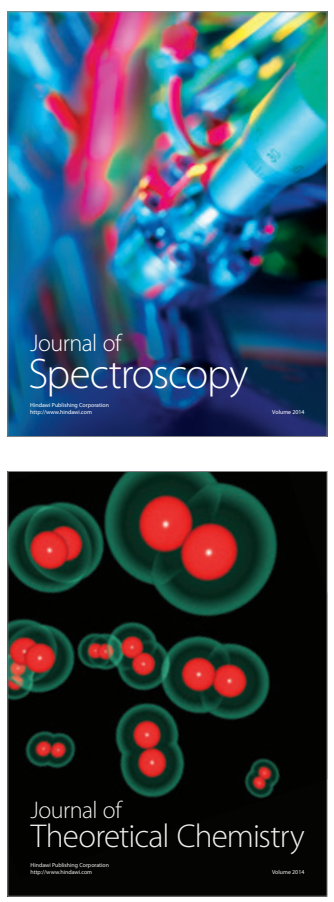
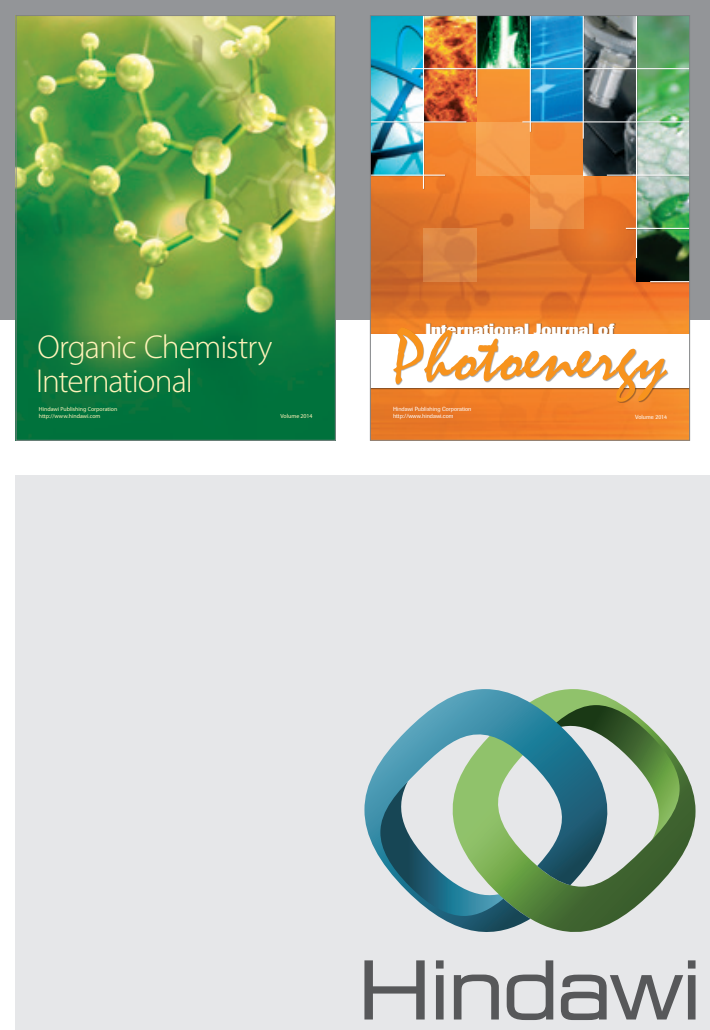

Submit your manuscripts at

http://www.hindawi.com
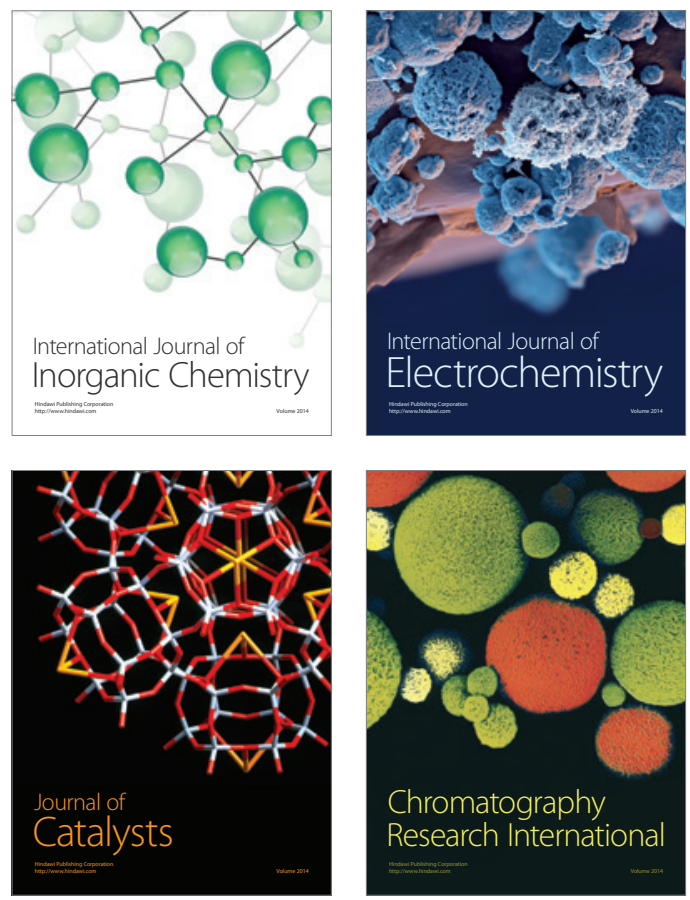
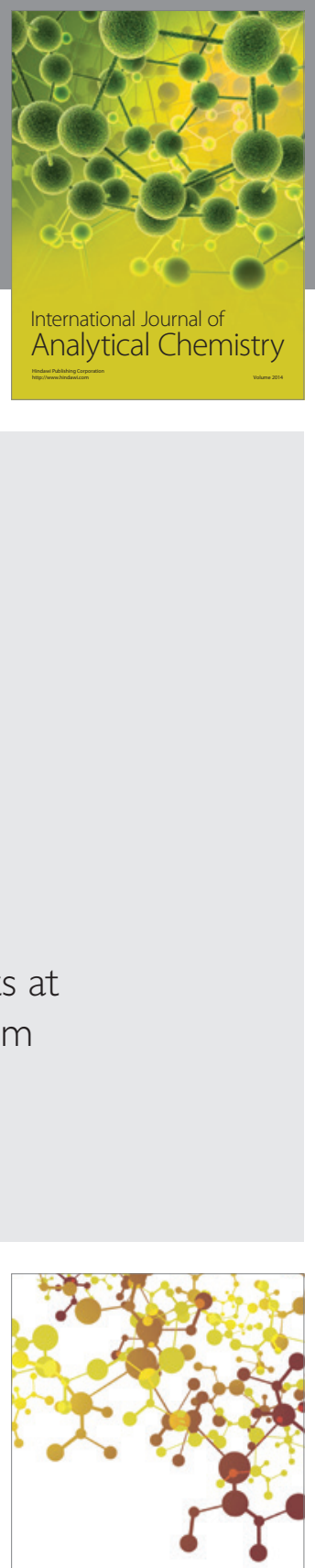

Journal of

Applied Chemistry
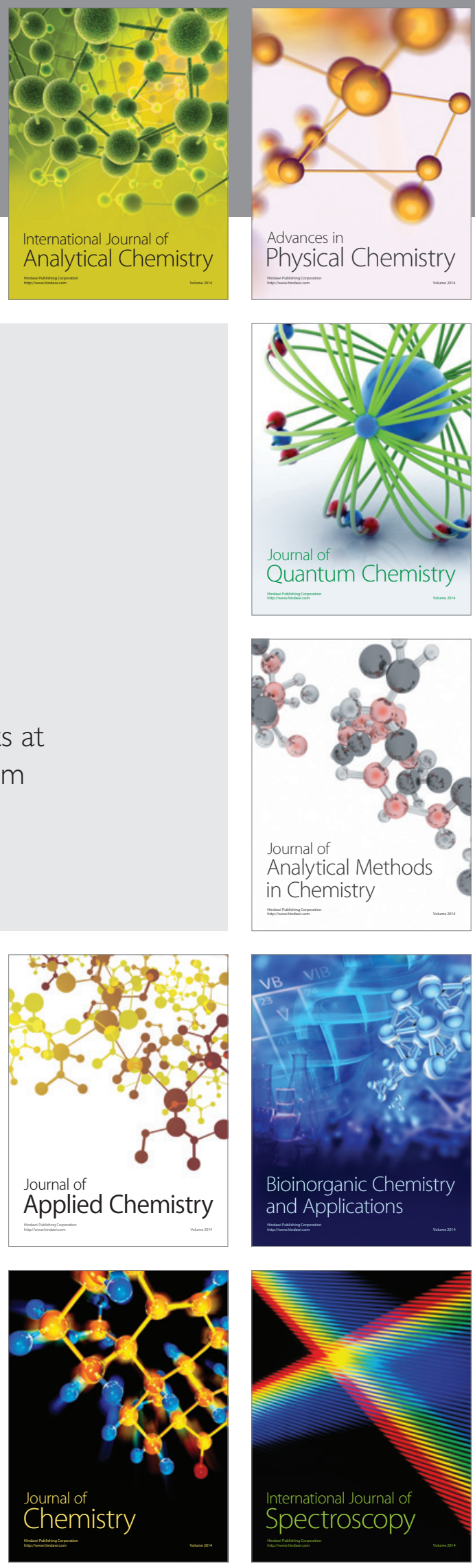